\title{
Türkiye Camilerinde Okutulan Hutbelerin Birlikte Yaşama Söylemleri Üzerine Sosyolojik Bir Değerlendirme: Adana Örneği*
}

\author{
Yrd. Doç. Dr. İslam Can \\ Selçuk Üniversitesi Beyşehir A. A. Uygulamalı Bilimler YO \\ Sosyal Hizmet Bölümü \\ islamcan@hotmail.com
}

Öz

Camiler Müslümanların gündelik hayatında büyük öneme sahip mekanlardır. Camilerde Müslümanlara, Cuma ve bayram namazlarında Diyanet İşleri Başkanlığı veya İl müftülükleri tarafından hazırlanan hutbeler okunur. Hutbeler, ibadet ve ahlak gibi konuların yanı sıra Müslümanların gündemini oluşturan siyasal, sosyal ve daha birçok konuda Müslümanlara telkinlerde bulunmayı amaçlamaktadır. Bu gündemler günümüz toplumlarında yaşanan ve büyük toplumsal ve siyasal dönüşümlere neden olan kaos, salgın, savaş, ayrımcılık, soykırım, göç, kentleşme, suç, açlık ve kuraklık gibi olaylardan oluşmaktadır. Bu olaylar, gerek dünya nüfusunun çoğunun doğrudan karşı karşıya kalması, gerekse de genellikle Müslümanların yoğun olarak yaşadığı coğrafyalarda cereyan etmesi bakımından önemlidir. Kaldı ki bu olaylarla birlikte, birlikte yaşama, farklılıklara saygı gibi konular da sosyal bilimlerin gündemine taşınmıştır. Bu çalışmada, İslam'ın birlikte yaşama kültürünün hutbeler üzerinden yeniden üretilmesi analiz edilecek ve hutbelerin söylem analizleri sosyolojik açıdan değerlendirilecektir. Bu bağlamda Cuma ve bayram namazlarında okunan hutbelerdeki "birlikte yaşama" söyleminin sosyolojik analizi yapılacaktır. Ayrıca "birlikte yaşama" ve "farklılıklara saygı" temalı hutbelerin söylem analizleri, bazı sosyal ve siyasal olaylar örnekliğinde tartışılacaktır. Bu amaçla 2013-2015 yılları arasında Cuma ve bayram namazlarında okutulan 87 hutbe incelenecektir. Bu hutbelerin yoğunlaştığı Suriye Meselesi, Suriyeli sığınmacılar, terör ve etnik çatışma gibi konular temelinde hutbelerin birlikte yaşama kültürünü inşa ettiği söylemler de sorgulanacaktır.

Anahtar Kelimeler: Diyanet İşleri Başkanlığı, hutbe, birlikte yaşama, Suriyeliler, Suriye meselesi.

\footnotetext{
* Bu makale 17-22 Mayıs 2017 tarihleri arasında İspanya'nın Sevilla şehrinde gerçekleştirilen III. Uluslararası Dini Araştırmalar ve Küresel Barış Sempozyumu'nda sunulan “Türkiye Camilerinde Okutulan Hutbelerin Birlikte Yaşama ve Çokkültürlülük Söylemleri Üzerine Sosyolojik Bir Değerlendirme" başlıklı bildirinin tam metnidir. 


\title{
A Sociological Evaluation of the Co-Existence Discourses of the Khutbahs Given in Turkish Mosques: The Case of Adana
}

\begin{abstract}
Mosques are important places in the daily lives of Muslims. In mosques, khutbahs, which are prepared by Presidency of Religious Affairs or Provincial Offices of Mufti, are given during the Jumuah and Eid prayers. Khutbahs aim at indoctrinating Muslims about political, social and the other issues that constitute the Muslims' agenda besides the subjects like worship and morality. These agendas consist of some problems such as epidemic, war, discrimination, genocide, migration, urbanization, crime, hunger and drought, which have been experienced in today's societies and which cause social and political transformations. These events are important in terms of both influencing the majority of World's population and generally occurring in the areas where Muslims have been intensively living. Moreover, issues like living together, respect for diversity, etc. have been moved to the agenda of the social sciences. In this study, re-production of the co-existence culture of Islam through the khutbahs will be analysed and discourse analyses of khutbahs will sociologically be evaluated. Within this context, sociological analysis of the "co-existence" discourse given in khutbahs during Jumuah and Eid prayers will be made. In addition, discourse analyses of the khutbahs themed "living together", "respect for diversity" will be discussed in the exemplification of some social and political events. For that purpose, 87 khutbahs given in Jumuah and Eid prayers between the years of 2013 and 2015 will be examined. In line with the issues such as the Syrian issue, Syrian asylum-seekers, terror and ethnic conflicts which these khutbahs deal with, the discourses that construct the culture of living together in the khutbahs will be questioned.
\end{abstract}

Keywords: Presidency of Religious Affairs, khutbah, co-existence, Syrians, issue of Syria. 


\section{GİRIŞ}

Günümüz dünyasında çoğulculuk, toplumların yeni ontolojik kurgusunu oluşturmakla birlikte bu yönüyle toplumun doğal bir yapısı haline gelmiştir. Bu yeni zemin, gerek küreselleşmenin getirdiği toplumsal dönüşümlerden, gerekse de buna bağlı olarak ortaya çıkan çoğul kimlikler ve ulus-ötesi kurumların artan rollerinden kaynaklanan farklılaşmış kimlikleri üretmeyi başarmıştır. Dolayısıyla bugünün toplumları, insanların geçmişte hiç olmadığı kadar birbirleriyle yakın yaşadığı ve kimliklerin, kültürlerin ve siyasanın farkındalığının üst düzeye çıktığı bir kompozisyonu da ortaya koymaktadır (Şan 2005: 69-70; Vatandaş 2002: XIV; Aktay 2003). Zira dünya nüfusunun önemli bir kısm1, savaş, ekonomik nedenler, eğitim, doğal afetler veya herhangi bir başka sebepten dolayı doğdukları yerleri terk ederek yeni yerleşim yerlerinde hayatını sürdürmekte; çok önemli bir kısmı da göç ettiği yerlerde sürekli kalamayarak yeni bir vatan arayışına yönelmektedir. Kaldı ki yaşadığımız dünya, neredeyse hiç kimsenin doğduğu yerde ölmesinin mümkün görünmediği bir savrukluğa doğru yol almaktadır (Aktay 1998: 13). Dünyanın görece bu yeni durumu, birden fazla kültürel öğenin aynı mekan veya toprak parçası üzerinde yaşamasını elzem haline getirmiştir. Öte yandan farklı sosyal unsurların bir arada yaşayabilme sorunsalı da, "çokkültürlülük", "sosyal veya kültürel uzlaşma", "kültürlerin birbirlerini anlaması", "kültürler arası iletişim" ve "birlikte yaşama" gibi kavramsallaştırmalarla (Aydın 2003: 42-43) sosyal bilimler çevresinde tartışılmaya başlanmıştır.

Tarihsel süreçte bir toplumdaki kültürel farklllıklar, idealleştirilen siyasi birliklerin karşılaştıkları en önemli sorunlardan birisini oluşturmuştur (Özensel 2012: 57-58). Farklı kültürlerin birlikte yaşadığı toplumlarda, toplumun üyeleri arasında etnik, kültürel, dilsel, dinsel, ideolojik vb. farklılıkların birlikte yaşamasını tesis etmek, bu düzlemin özgün bir hukuk geliştirerek meşrulaştırılmasını sağlamak, ayrıca bu farklı yapılar arasında bir tür "ulusal birlik" hissinin oluşturulmasını sağlamak, günümüz çokkültürlü toplumların temel problemlerindendir (Özensel 2012: 57). Esasında kültürel farklılıkların bir toplumda problem alanı olarak ortaya çıkması doğal bir gelişmedir. Birçok kültürün taşıdığı tüm tarihsel, toplumsal ve geleneksel potansiyeliyle, hakim ve iktidar olan bir kültürün formuna sokulmak istenmesi, kuşkusuz "kültürel militarizm" olarak adlandırılacak bir politikadır. Çünkü Özensel'in de (2012: 58) dikkat çektiği üzere, her kültürün sahip olduğu değer ve normlar, bir başkası ile kıyaslanamaz önceliğe sahiptir.

Dünyanın birçok ülkesinde olduğu gibi Türkiye'de de birlikte yaşama konusunda ciddi sorunlarla karşılaşılmaktadır. Bugünün Türkiye'sinde etnik temelde yaşanan ve daha çok "Kürt Sorunu" olarak ifade edilen birlikte yaşama sorunu (Özensel 2013: 3; Can 2013: 127), son yıllarda Suriye Savaşı nedeniyle Türkiye'ye göç eden Suriyeli sığınmacılarla birlikte "Suriyeliler Sorunu" gibi bir meseleyi de kapsamı içerisine almıştır. Türkiye'de birlikte yaşama konusu sadece etnik köken üzerinden ele alınan bir konu olmamakla beraber "dinsel ve mezhepsel farklılıkların yanı sıra farklı inanç ve düşünce temelinde bir araya gelen çeşitli toplulukların farklı yaşam biçimlerini pratik hayatta gerçekleştirme" (Özensel 2013: 3) sorunu olarak da karşımıza çıkmaktadır. Bu bağlamda Türkiye'nin, gerek birlikte yaşamaya ilişkin önemli olay ve sorunlarla karşı karşıya kalması, gerekse de birlikte yaşamanın sağlam toplumsal temellere oturtulması için atılan büyük adımlar, siyasal ve bürokratik seçkinlerin ve aynı zamanda toplumun birlikte yaşama pratikleriyle yüzleşmesini ve kendini muhasebe etmesini de beraberinde getirmiştir. 2009 yılından itibaren başlatılan açılım politikalarıyla (Can 2015: 203-219) Çözüm Süreci, Alevi Açllımı, Roman Açılımı ve 
Azınlık hakları gibi konuların gündeme oturması, bunun yanı sıra Suriye Meselesi ve yaklaşık 3 milyon Suriyeli sığınmacının toplumun gündelik hayatında dikkat çekmesi, birlikte yaşama sorunsalını sürekli beslemiş ve diri tutmuştur. Bu toplumsal soruna din kurumunu temsil eden Diyanet İşleri Başkanlığı kayıtsız kalmayarak, özellikle Cuma ve Bayram namazı hutbelerinde bu konuyu işlemiş ve İslam öğretilerine uygun bir dil geliştirmeye çalışmıştır. Buradan hareketle bu çalışmada, Diyanet İşleri Başkanlığı'nın hazırladığı/hazırlattığı hutbelerin söylem analizleri sosyolojik açıdan ele alınacak olup hutbelerde İslam'ın birlikte yaşama tasavvurunun hangi bağlamlar temelinde üretilmeye çalışıldığı tartışılacaktır. Bu kapsamda, birlikte yaşama ve farklılıklara saygı temalı hutbelerin söylem analizleri, Suriye Meselesi, Suriyeliler, sığınmacılar, terör ve etnik çatışma gibi bazı sosyal ve siyasal olaylar örneğinde irdelenecektir. Bu amaçla, bu meselelerin yoğun olarak hissedildiği 2013 yılı Kasım ayı ile 2015 yılı Ağustos ayı aralığında Cuma ve bayram namazlarında okutulan 87 hutbe ele alınacaktır.

\section{HUTBE, SÖYLEM VE SIYYASET}

Camiler ibadet mekanları olmasının yanı sıra çeşitli faaliyetlerle din eğitiminin temel konuları olan iman, ahlak, ibadet gibi konuların ele alındığı ve bir bakıma halk eğitiminin yapıldığı toplum eğitim merkezlerinin ilk sıralarında gelmektedir (Doğan 1998: 5). Bu eğitim yöntemlerinden birisi olan hutbe, Müslümanların çoğuna haftada en az bir defa yöneltilen dini, toplumsal ve politik meseleleri konu alan mesajlardır. Hutbe, Arapça "hatabe" fiilinden türeyen bir isim olmakla birlikte bir topluluk karşısında "hatibin yaptığı konuşma"ya denmektedir (Zengin 2008: 380). Yaygın din eğitimi olarak da kabul edilen hutbe, cuma namazında namazdan önce, bayram namazında ise namazdan sonra imamı minbere çıkarak cemaate hitap etmesidir.

İslam Tarihi'ne bakıldığında Cuma hutbelerinin doğrudan veya sembolik olarak siyasi bir mesaj taşıdığı görülmektedir (Doğan 1998: 15). Ne var ki devletlerin siyasi geleneklerinde bağımsızlığın ve otoritenin sembolleri olarak bir takım ritüellerin olduğu bilinmektedir. Bu yönüyle Türk-İslam devletlerinin geleneğinde yer alan sancak, hutbe ve sikkelerde hükümdarın adının geçmesi, devlet otoritesinin tesis edilmesine yönelik bir göstergedir (akt. Külekçi 2013: 308). Ayrıca Hz. Muhammed'in, çeşitli rivayetler olsa da, ilk hutbeyi Mekke'den ayrıldıktan sonra Medine'de ya da Medine yakınlarındaki bir camide vermiş olması (Külekçi 2013: 313-314), hutbenin bir "siyasal otorite" yetkinliği ya da "bağımsızlık göstergesi" ritüeli olduğunu da ortaya koymaktadır. Esasında İslam bilginlerinin Cuma namazı için "boyunduruk altında olmama", "özgür olma" ictihadları da, hutbenin bir "siyasal bağımsızlık" geleneği olduğunu açıklayan bir husustur.

Hutbeler, "İslam tarihi boyunca birçok dini ve toplumsal işlevinin yanında, politik bir konu olarak da telakki edilmiş, iktidarın bir operasyon alanı olarak görülmüştür" (Demir 2012: 8). Osmanlı döneminde hutbelerin, ${ }^{1}$ iktidarın politikasına uygun bir dil ve söylem ile hazırlandığı bilinmektedir (Zengin 2008: 380-381). Cumhuriyet'in ilanından sonra da bu geleneğin devam ettirildiği görülmektedir. Çünkü toplumun din kurumunu organize etmek

\footnotetext{
${ }^{1}$ Osmanlı Devleti'nde hutbeler, Arapça olarak okutulmaktaydı. Osmanlı son döneminde ve özellikle II. Meşrutiyet döneminde hutbelerin içeriklerinin düzeltilerek zaman ve zemine uygun hale getirilmesi, dinlenilecek uzunlukta olması, bidatlardan arındırılması ve Türkçe okutulması gibi konular merkezinde bazı tartışmalar yapılmıştır. Cumhuriyet'in ilanından sonra da hutbeler Arapça okunmaya devam etti. Ancak 1925 yılından itibaren Diyanet İşleri Reisi Rıfat Börekçi'nin talimatıyla ayet ve hadislerin Arapça ve Türkçe, öğüt kısmının da Türkçe okutulması kararlaştırıldı (Yaşaroğlu 2016: 95-96; Doğan 1998: 18-21). Dolayısıyla bu düzenleme, günümüze kadar ulaşan hutbenin de formunu belirlemiş oldu.
} 
amacıyla Cumhuriyet'in ilk yıllarında ve hilafetin kaldırılmasından sonra 3 Mart 1924 tarihinde kurulan Diyanet İşleri Reisliği, 1965 ve 1982 yıllarında çıkarılan yasalarla, kuruluş ve görevleri kanunlarca belirlenmiş bir teşkilattır. 1965 yılında çıkarılan 633 sayılı yasayla Diyanet İşleri Başkanlığı adını alan teşkilat, yasada da ifade edildiği üzere Başbakanlığa bağlı olarak ""İslam dininin inançları, ibadet ve ahlak esasları ile ilgili işleri yürütmek, din konusunda toplumu aydınlatmak ve ibadet yerlerini yönetmek üzere" kurulmuş olup 1982 Anayasasının 136. Maddesiyle de "laiklik ilkesi doğrultusunda, bütün siyasi görüş ve düşünüşlerin dışında kalarak ve milletçe dayanışma ve bütünleşmeyi amaç edinerek, özel kanununda gösterilen görevleri yerine" getirmekle yükümlü tutulmuştur (Zengin 2013: 121).

Hutbeler, Cumhuriyet'in ilanından sonra bir nevi "yaygın eğitim" modeli olarak devrimlerin halka anlatıldığı, böylelikle Batılı vatandaş tipolojisinin yani "seküler" bir modelin "dinsel" bir araçla inşa edilmeye çalışıldığı söylemler üretmiştir. Bunun yanı sıra Demir'e (2012: 8) göre bu hutbelerde, Cumhuriyet'in faziletlerine vurgu yapıldığı, askerliğin ve militarizmin övüldüğü, vatan sevgisinin ve vatana bağllık/fedakarlığın kutsanarak milli kimliğin oluşturulduğu, çağdaşlaşma ülkülerine, bilimsel ve teknolojik gelişmelerin önemine değinildiği görülmektedir. Bu dönemde Ahmet Hamdi Akseki'nin hazırladığı hutbelerin, siyasal otoritenin söylemiyle örtüşmesi de ayrıca önem arz etmektedir. Cumhuriyet tarihinde iktidar seçkinleri ya da seçkinlerin temsilciliğini yaptığı resmi ideoloji söylemleri değişmese dahi, hutbelerin devlet ya da hükümet politikalarının değişimine endeksli bir söylem değişikliğine gittiği de görülmektedir. Kaldı ki hutbeler, değişen siyasal, sosyal ve ekonomik konjonktüre göre birbirine aykırı söylemler de üretebilmiştir. Örneğin "Cumhuriyetin ilk dönemlerinde nüfusun artırılmasını tavsiye sadedinde, dönemin Cumhurbaşkanı İsmet İnönü tarafından camilerde hutbe okutulduğu bilinmektedir. O zamanın şartlarında savaşlardan çıkılan bir ortamda çok çocuk yapmak meşru bir ihtiyaç halini almıştı. Aradan geçen zaman içerisinde ekonomik ve sosyal ihtiyaçlar değişince önceleri nüfus planlaması, ardından da aile planlaması ile ilgili hutbe ve vaazların okutulduğu ve bunlarla ilgili dini delillere, Hz. Peygamber ve İslam tarihinden örnekler sunma arayışına girildiğine" (Koçyiğit 2013: 427) tanıklık edilmiştir.

Hutbelerin konu seçiminde dönemin siyasal konjonktürünün belirleyici olduğu bilinmekle birlikte konu belirleniminde, siyaseti dizayn eden siyaset dışı güçlerin olduğu da su götürmez bir gerçekliktir. Baskı grupları ve askeri bürokrasi, kuşkusuz bu güçlerin başında gelmektedir. Bu açıdan ele alındığında, askerin siyaset üzerindeki baskısı, gerek hutbelerin merkezileşmesinde gerekse de kontrol altında tutulmasında önemli bir mekanizma olarak işletilmiştir. Örneğin Yaz Kur'an Kurslarına yaş sınırlaması getirildiği dönem olan 2001-2006 yılları arasında okutulan hutbeler incelendiğinde, çocukların Yaz Kur'an Kurslarına gönderilmesini teşvik eden hutbelerin okutulmadığı, 2006 yılından sonra ise değişen konjonktüre bağlı olarak çocukların Yaz Kur'an Kurslarına gönderilmesini içeren hutbelerin okutulduğu anlaşılmaktadır (Demir 2013: 99-100). Son dönemde askeri bürokrasinin bu tür müdahaleciliğinin yaklaşık son beş yıldır değiştiği de ifade edilmelidir.

Günümüzde yaklaşık 80.000 camide Cuma ve bayram namazları kılınmaktadır (Demir 2013: 96). Türkiye'de İslam dinine ilişkin din hizmetlerinin organizasyonunu ve yürütülmesini sağlayan, toplumun bilgilendirilmesi ve bilinçlendirilmesi konusunda önemli bir sosyal sermayeye sahip olan Diyanet İşleri Başkanlığı'nın Cuma ve Bayram namazları için hazırlamış olduğu hutbeler, kuşkusuz oldukça önemlidir. Çünkü çeşitli verilere bakıldığında ortalama 20 milyon Müslümanın Cuma namazı kıldığı görülmektedir (Yaşaroğlu 2016: 106; Demir 2012: 6; Aygün 2011'den akt. Demir 2013: 96). Bu beşeri 
sermaye, Türkiye'nin diğer kurum ya da alanlarında yapılan organizasyonlarla kıyaslandığında, her hafta gerçekleştirilen en yoğun faaliyetlerden biridir. Bilgilendirme, bilinçlendirme, nasihat etme, telkinlerde bulunma gibi eğitici yönleri bulunan hutbelerin, taşıdığı potansiyel açısından kitleler üzerinde büyük bir etkisinin olduğu da bu açıdan değerlendirilebilir.

Diyanet İşleri Başkanlığı (DİB), hutbelerle ilgili bazı dönemlerde önemli değişikliklere gitmiştir. Bu değişikliklerden biri, hutbelerin hazırlanmasında inisiyatifin taşra teşkilatlarına yani il müftülüklerine devredilmesidir. DİB, 1999 yllından itibaren tüm il müftülüklerine hazırlayıp gönderdiği "merkezi hutbe" politikasını, din hizmetleri personelinden aldığı dönütlere referansla 2006 yılında sona erdirmiştir. Yeni uygulamaya göre her ilin müftülüğü hutbeleri hazırlayacak ve muhtelif zamanlarda merkezden gelen hutbeleri de camilerde okutacaktır (Demir 2013: 98-99; Yaşaroğlu 2016: 97-98). Her ne kadar bu uygulama günümüzde yürürlükte olsa da, son yıllarda yaşanılan yoğun siyasal gelişmeler vesilesiyle hutbeler çoğunlukla DİB'e bağlı Din Hizmetleri Genel Müdürlüğü (DHGM) tarafından hazırlanmakta ve il müftülüklerine gönderilmektedir. DHGM ise, gelecek üç aylık periyotlar için okutulacak hutbeleri önceden hazırlamaktadır. Ancak ülke gündemini yoğun olarak meşgul eden olaylar veya toplumun sağduyulu davranmasına ilişkin telkinler ve tavsiyeler söz konusu olduğunda, ivedilikle konuyla ilgili hutbeler hazırlanıp okutulmaktadır (Demir 2013: 99). Örneğin son yıllarda yaşanan Suriye İç Savaşı, Filistin ve Mescid-i Aksa meselesi, Soma ve Ermenek'teki maden faciaları, Özgecan Aslan'ın ve Suriyeli annenin çocuğuyla birlikte Sakarya'da öldürülmesi gibi Türkiye gündemini sarsan olaylar, son dönem hutbelerde değinilen konular arasında yer almaktadır.

Diyanet İşleri Başkanlığı, din görevlilerinin vaaz ve hutbelerde nasıl bir tutum izlemesi ve ne tür bir toplumsal dil geliştirmesi gerektiği hususunda, kendine bağlı Hukuk Müşavirliği'nce genelgeler hazırlatmaktadır. Son on yıl içerisinde bu genelgelerden ilki 2007 yılında, diğeri ise 15 Temmuz darbe girişimi üzerine 2016 yılında yayınlanmıştır. 2007 yılında Dış Genelge başlığıyla yayınlanan genelgede, din görevlilerinin şu hususlara dikkat etmeleri istenmektedir:

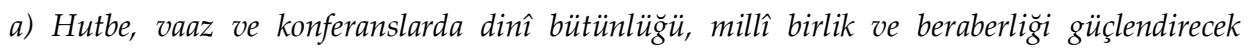
konulara ă̆ırlık verilecektir. Yıkıcı, bölücü propagandalara, zararlı akımlara karşı gerekli tedbirler alınacaktır. b) Vaaz ve hutbelerde toplumun dinî, ilmî ve ahlâkî konularda bilgi ve kültürünün artırlması hedef alınacak, fitne, tefrika ve bölücülüğ̈ün kötülü̈̆̈̈, sevgi, actma duygusu, af ve hoş görü gibi hasletlerin fazileti, akraba, komşu ve insan hakları, düzenli ve tutumlu yaşama, sosyal dayanışma ve yardımlaşmanın önemi, lüks, israf ve düzensiz yaşamanın zararları gibi yurt kalkınmamızın güçlenmesine yardımo olacak ve millî bütünlüğümüzü pekiştirecek konulara yer verilecektir. c) Hutbe, vaaz ve konferanslarda samimî, duygulu, toplumun içinde bulundŭ̆u manevî hastalıkları tedavi edici, ölçülü, yapıcı, uyarıcı, teşvik edici, sevdirici ve müjdeleyici ifadeler kullanılacak; aşırı, kırıcı, itham edici ifadelerden; bıktırıcı ve mesnetsiz sözlerden, dinî ve ilmî kesin bilgilere uymayan görüşlerden kaçınılacaktır. ç) Vaaz ve hutbelerde; siyaset ve şahsiyat yapmaktan kaçınılacak, konu bütünlü̆̆̈̈ sağlanacak, iç ve dış politik konulara kesinlikle girilmeyecektir (DİB 2007, http://www2.diyanet.gov.tr).

Hutbe, söylem ve siyaset ilişkisi bakımından, her ne kadar çalışmanın araştırma konusuyla doğrudan ilintili değilse de, 15 Temmuz 2016 ve sonrasında Diyanet İşleri Başkanlığı'nın sürdürdüğü politikaya dikkat çekmek gerekmektedir. Diyanet İşleri Başkanlığı, 05.09.2016 tarihinde yürürlüğe giren “15 Temmuz 2016 Genelgesi”yle, 2007 yılı genelgesinde belirtilen hususlara bazı eklemeler yapmışır. 15 Temmuz Genelgesi, darbe 
teşebbüsünü gerçekleştiren FETÖ/PDY terör örgütüne yönelik DİB'in aldığı kurumsal kararlar açısından da önemlidir. 15 Temmuz Genelgesi'nde yer alan ifadeler şunlardır:

(1) Cuma günleri camilerde Başkanlık merkezinden gönderilen hutbelerin okunmasına titizlikle riayet edilecektir. Hutbe metninde hiçbir surette ilaveler ve çıkarmalar yapılmayacaktır. (2) Yetkisiz ve izinsiz olarak hiç kimsenin hutbe okumasına, vaaz ve irşat görevi yapmasına müsaade edilmeyecektir. Vaazlar ezanla sonlandırılacak ve cemaatin ezan dinlemesine imkân sağlanacaktır. (3) Başkanlı̆̆ımız mensubu olmayıp kendisine vaaz ve irşat yapma izni verilenlerin vaazlar yakından izlenecek, vaaz ve irşat hizmeti esnasında Başkanlığımızca belirlenen prensiplere uygun hareket etmeyenlere kesinlikle müsaade edilmeyecektir. Söz konusu prensiplere aykırı vaaz ve irşat hizmeti sunduğu tespit edilen Başkanlık personeli hakkında da gerekli kanuni işlem yapılacaktır. (4) Hutbe, vaaz ve konferanslarda millî birlik ve beraberliği güçlendirecek konulara ă̆ırlık verilecektir. Yıkıcı, bölücü propagandalara, zararlı akımlara karşı gerekli tedbirler alınacaktır. (5) Vaaz, hutbe ve konferanslarda toplumun dinî, ilmî ve ahlâkî konularda bilgisinin artırılması hedef alınacak, fitne, tefrika ve bölücülüğ̈̈n kötülü̈̆̈̈̈, sosyal dayanışma ve yardımlaşmanın önemi gibi millî bütünlüğ̈̈müzü pekiştirecek konulara yer verilecektir. (6) Hutbe, vaaz ve konferanslarda samimî, duygulu, toplumun içinde bulunduğu manevî sorunlar tedavi edici, ölçülü, yapıcı, uyarıcı, teşvik edici, sevdirici ve müjdeleyici ifadeler kullanılacak; aşırı, kırıcı, itham edici

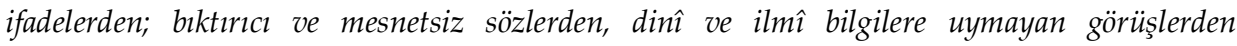
kaçınılacaktır. (7) Vaaz ve hutbelerde; siyaset ve şahsiyet yapmaktan kaçınılacak, konu bütünlü̈̆̈̈ sağlanacak, iç ve dış politik konulara kesinlikle girilmeyecektir. (8) Vaaz ve irşat hizmetlerinin aksamasına ve doğacak boşlukların diğer unsurlar tarafindan doldurulmasına meydan verilmemesi için gerekli tedbirler alınacaktır. (9) Cami ve Kur'an kurslarında kadınlara ve erkeklere özel olarak düzenlenen vaaz ve irşat programlarında FETÖ/PDY vb. yapılanmaların İslâm'a aykırı yönleri anlatılacak ve benzer hatalara düşülmemesi için yapılması gereken hususlar dile getirilecektir (DIBB 2016a, http://wwww2.diyanet.gov.tr).

Hutbe, söylem ve siyaset bağlamında Diyanet İşleri Başkanlığı'nın uygulamaları, son dönem hükümet politikaları açısından değerlendirildiğinde, hükümetle uyumlu bir yürütmeye sahip olduğu görülmektedir. Siyasetin asker, bürokrasi ve finanstan oluşan iktidar seçkinleri tarafından yönlendirildiği geçmiş dönemlerde DİB, Müslüman toplumun beklentilerini göz ardı eden bir stratejiyi misyon haline dönüştürmüştür. Ancak son dönemlerde toplumun karşı karşıya kaldığı önemli sosyal problemlere, hükümetin sosyal politikalarıyla uyumlu olarak katkı sağlayan bu kurum, birlikte yaşama pratiğini söyleme dönüştürme, etnik, dini ve mezhepsel ayrışmaların İslam dininin doğasına aykırı olduğu fikriyatını çeşitli faaliyetler kapsamında tesis etmeye çalışma gibi bir strateji geliştirmektedir. Bununla birlikte yardımlaşma ve dayanışma, akrabalığın ve komşuluğun önemi, İslam kardeşliğinin birlik ve beraberliği güçlendirmesi vb. konularla da, sosyal sermaye üretimine katkı sağlama ve böylelikle sosyal ağların gücünü tedavüle sokarak toplumu inşa edici sosyal politikaları hayata geçirmeye çalışmaktadır. Ayrıca 15 Temmuz darbe girişimi sırasında ve sonrasında, kurumsal geleneğinin aksine darbeye karşı durması, sivil inisiyatiften yana tavır koyması, sahip olduğu resmi din söylemine yaslanarak açıklamalarda bulunması, DİB'in durduğu zeminin konum değiştirdiğini göstermesi açısından da önemlidir. Kaldı ki darbe gecesi özel bir televizyon kanalına bağlanan Diyanet İşleri Başkanı Prof. Dr. Mehmet Görmez'in, doğal afetler gibi olağanüstü durumlara telmihle, tüm cami görevlilerin minarelerden sala okumasını istemesi ve böylelikle sivil iradenin askeri darbeye karşı durmasına destek olması kuşkusuz Türkiye siyasi tarihinde ilk defa gözlemlenen bir durumdur. Bununla birlikte önceki dönemlerden farklı olarak darbe 
teşebbüsü sonrasında DİB'in 3-4 Ağustos 2016 tarihlerinde Olağanüstü Din Şurasını toplayarak gerek sivil iradeye yapılan darbe teşebbüsüne karşı durması, gerekse de bu teşebbüsü gerçekleştiren FETÖ/PDY terör örgütünün dini bir cemaat olmadığına vurgu yapmış olması (Yenişafak 2016b, http://www.yenisafak.com), DİB'in hükümet tarafından ortaya konan resmi-sivil din politikasına uygun davrandığını da göstermektedir. Son olarak DİB'in Temmuz 2017' de hazırladığı "Kendi Dilinden FETÖ: Örgütlü Bir Din İstismarı" (DİB 2017) adlı rapor, DİB Başkanı Prof. Dr. Mehmet Görmez'in yaptığı basın toplantısıyla kamuoyuyla paylaşılmıştır. FETÖ terör örgütü lideri Gülen'in kitaplarından alıntılar yaparak, dini cemaat kisvesinde yıllardır insanları kandıran bu örgütün İslam inanç esaslarıyla bağdaşmadığını ortaya koyan bu rapor, bu terör örgütünün esasında yalan ve hurafelerle dolu tahrif edilmiş bir din inşa etmeye çalıştı̆̆ını ortaya koymaktadır (DİB 2017). Raporda Diyanet İşleri Başkanlığı'nın görev ve sorumluluklarının farkında olduğunu belirten Görmez, 15 Temmuz darbe gecesi ve sonrasında Dï'in darbeye karşı durmasıyla birlikte oluşturduğu yeri ve konumunu da güçlendirmiştir. Çünkü Görmez'e göre;

İslam dininin temel hedefleri arasinda 'dinin korunmasi' önemli bir yer tutmaktadir. Dinin sağhlkh anlaşılması ve aktarlması ise din güvenlĭğinin birinci şartıdır. FETÖ/PDY ve benzeri zihniyete sahip olan yapıların inancımızı ve insanımızı sömürmesine engel olmak için, köklü ilim geleneğimizden beslenen sağhlklı bir din anlayışının desteklenmesi ve yaygıılaştırılması zaruridir (Görmez 2017).

\section{KAPSAM VE YÖNTEM}

Söylem, genel olarak, dilin sözel ya da yazılı bir biçimde aktüelleşmesi süreci ya da bir etkinlik alanı, faaliyet türü veya disipline özgü kavramsallaştırmalar bütünü (Cevizci 2002: 969) olarak ifade edilebilir. Söylem; kişi, düşünce, yaklaşım, ideoloji ya da kurumun süreç içerisinde değişen koşullara veya konjonktüre göre değişkenlik gösterebilir. Her yeni söylem, yeni bir stratejiyi ya da politikayı yürürlüğe koyar. Bir kurum olarak Diyanet İşleri Başkanlığı da dönemler içerisinde farklı söylemler üreterek mevcut siyasal sistemle uyumlu hareket etmiştir. 1994 ve 2007 yıllarında hazırlanan hutbelerin söylem farklılaşmalarını ele alan Özbolat'ın (2013: 669) çalışmasında, hutbeler söylem bakımından karşılaştırılmış ve genel olarak hutbelerin beş boyutta söylem değişikliğine gittiği görülmüştür. Bu boyutlar; "(1) toplumsal hayatın iman ve ibadetlerle tanziminden kişilerarası ilişkilerle toplumsal hayatın düzenlenmesine, (2) dini değerlerden dini ve milli değerlere vurgu yapan bir çizgiye, (3) hiyerarşi yerine eşitlikçi bir çizgiye, (4) dışlayıcı bir söylemden kuşatıcı bir söyleme, (5) tek sebepli açıklamalardan çoklu açıklama biçimlerine yönelim değişimin boyutlarını oluşturmaktadır" (Özbolat 2013: 669). Özbolat'ın dikkat çektiği bu tür söylem değişimi, 2007 yılı sonrasında hazırlanan hutbelerde de karşılaşılan bir durumdur.

Diyanet İşleri toplumun gündemini oluşturan, küresel ve/veya ulusal düzeyde gelişen siyasal ve sosyal olaylara yönelik bir strateji oluşturmakta, bu stratejiye uygun söylemleri ise çoğunlukla hutbeler aracılığıyla toplumun ilgisine sunmaktadır. IŞID ve İslamafobia gibi Müslümanlar ile terörü eşleştirme girişimi, İslam coğrafyası ve Suriye'deki savaş, Arap Baharı, Mescid-i Aksa ve Filistin meselesi, etnik ve dini ayrımcılık uygulamaları gibi dünya gündemini meşgul eden olayların yanı sıra kadına şiddet, Suriyeli sığınmacılar, doğal afetler ve maden faciaları, kaos ve sosyal kargaşa gibi ulusal meselelere yönelik Dİ, birlikte yaşama ahlakını ve kültürünü oluşturabilme, farklılıklara ve yaşam hakkına saygı duyma, sığınmacılara yardım etme, kardeşliğin toplumsal önemi gibi söylemler geliştirme yoluna gitmiştir. Bu temalar içerisinde "birlikte yaşama" söylemi, çokça dile getirilen ve hutbelerde 
hatırlatılan bir durumdur. Ayrıca DİB'in her yıl kutlu doğum haftasında bir tema üzerinde durduğu ve bu temanın yıl boyunca yapılan etkinlerin ana gündemini oluşturduğu bilinmektedir. DİB, son on yılın iki yılında "birlikte yaşama"yı tema olarak işlemiştir. 2008 yılı kutlu doğum haftasının teması "İslam Medeniyetinde Bir Arada Yaşama Tecrübesi" (DİB 2009) iken, 2015 yılının kutlu doğum haftası için belirlenen tema ise, "Hz. Peygamber ve Birlikte Yaşama Ahlakı" olmuştur.

Hutbelerle ilgili literatürde yeterli düzeyde çalışmanın olmaması, araştırmacıların çokça değindiği bir husustur. Bu duruma dikkat çeken ve hutbelerle ilgili çalışmalar yapan Demir'e (2013: 97) göre "kitlelere ulaşmada önemi bu kadar açık bir araç olan hutbeler üzerinde yeterince araştırma ve akademik çalışma yapıldığı söylenemez. YÖK tez tarama kataloğundan hutbe ile ilgili hepsi de yüksek lisans olmak üzere sadece 15 tez tespit edilmiştir. Bunlardan 5'i din eğitimi, 4'ü hadis ile ilgilidir. Birer adet de Nuğbetu'r-Raşşaf min Hutbeti'il Keşşaf, iletişim, kadına bakış, Peygamberimizin hutbe tarzı, Ömer b. Abdulaziz' in hutbe dili, Cuma hutbeleri üzerinden resmi İslam'a bakış ile ilgilidir" (Demir 2013: 97). Ancak hutbeler gerek içerik ve gerekse de söylem veya metodolojik olarak birçok alanla irtibatı kurularak çalışılmalıdır. Bu anlamda hutbelerin, sosyolojik, politik, ekonomik, psikolojik, eğitsel, iletişimsel ve daha birçok açıdan ele alınması gerekmektedir (Demir 2012: 6).

Yakın dönem hutbe konularına ilişkin birkaç veriyi değerlendirdiğimizde, doğrudan toplum sorunlarıly ilgili okutulan hutbelerin oranının düşük olduğu görülmektedir. Zengin'e (2013: 132) göre son dönem hutbeleri incelendiğinde hutbeler, beş ana konuda toplanmaktadır. Bunlar; inanç, ibadet, ahlak, dini gün ve geceler (milli gün ve bayramlar) ve toplumsal konular (Zengin 2013: 132). Bu kapsamda Beşirli'nin 2001-2005 yılları arasında okutulan 273 hutbeyi sosyolojik açıdan ele aldığı çalışmasında, 98 hutbenin (\% 36) toplumsal konuları, diğer hutbelerin (\% 64) ise ibadet, inanç, ahlak, din ve milli gün ve gecelerle ilgili konuları ele aldığı anlaşılmaktadır (2006: 148-150). 2013 yılında DİB'in hazırladığı Din Hizmetleri Raporu'nda ise, 2013 yılı içerisinde hazırlanan hutbelerin \% 15'inin "toplumsal" başlığı altında toplanabileceği görülmektedir. "Toplumsal" başlığı kapsamında birlik, beraberlik, eğitim, bilim, akıl, yardımlaşma, dayanışma, tüketim bilinci gibi konulara ağırlık verilmekle birlikte en az değinilen konuların ise hayvan hakları, yetim/öksüz hakkı, görgü kuralları, selamlaşma gibi konular olduğu görülmektedir (Yaşaroğlu 2016: 103).

Bu çalışma kapsamında, 22.11.2013-21.08.2015 tarihleri arasında okutulan ve 87 Cuma ve bayram namazı hutbeleri incelenmiştir. Bu dönem ve hutbelerin seçilmesinde, hem Türkiye'nin bu dönemde yaşadığı siyasal ve toplumsal olayların etkisi hem de Suriyeli sığınmacıların bu dönemdeki yoğun göçüyle beraber "birlikte yaşama" konusunun sıklıkla gündeme gelmesi etkili olmuştur. Ayrıca Diyanet İşleri Başkanlığı'nın bu süreçlerle bağlantılı olarak, bu dönemde hazırladığı hutbelerin çoğunlukla "birlikte yaşama" temalı olması da, çalışmanın bu döneme odaklanmasını sağlamıştır. Bu çalışma kapsamında değerlendirilen hutbeler incelendiğinde, hutbelerin \% 28'inin "toplumsal" konularla, \% 72 'sinin ise "ibadet, inanç, ahlak ve dini ve milli gün ve geceler"le ilgili olduğu görülmektedir. Kuşkusuz hutbelerin dili, sadece toplumsal olaylar ya da sadece dini konuları ele alan arıtılmış bir dil değildir. Kaldı ki hutbelerde toplumsal bir sorunu merkeze alırken ibadet, ahlak ve inanç gibi dini referanslardan faydalanılırken, inanç, ibadet ve ahlak gibi salt dini konularda da toplumun sorunları üzerinden tespitler yapılabilmektedir. Dolayısıyla incelediğimiz hutbelere dair yukarıdaki istatistiğin, toplumsal ya da dini bir meselenin merkeze alınma ve bu mesele üzerinden temellendirilmesi yöntemine göre

SEFAD, 2017 (38): 507-532 
oluşturulduğunu hatırlatmak gerekecektir. Bu bağlamda ele alındığında çalışmamızın da konusunu oluşturan "birlikte yaşama" meselesi, yakın dönem hutbelerin değinilen önemli konularından biri haline gelmiştir. Türkiye' de son beş yılda gerek iç gerekse de dış kaynaklı problemlerin toplumun gündemini olabildiğince meşgul etmesi, "birlikte yaşama" ahlakının tesis edilmesini kuşkusuz beraberinde getirmektedir. İncelenen 87 hutbede ise birlikte yaşama konusunun sadece toplumsal sorunların ele alındığı hutbelerde değil, ibadet, inanç, ahlak ve dini ve milli gün ve geceleri konu alan hutbelerde de işlendiği görülmektedir. Buna göre konu ayrımı yapılmaksızın ve konusu doğrudan birlikte yaşama ahlakı olmasa da, tüm hutbelerin \% 22'sinde "birlikte yaşama" nın ahlaki, itikadi, tarihsel ve toplumsal boyutlarına az ya da çok değinildiği ortaya çıkmaktadır. Bunun yanı sıra DHGM'nin hazırladığı hutbelerde, Türkiye'de ve dünyada gerçekleşen siyasal ve sosyal olaylara değinilirken, Adana Müftülügü̈'nün hazırladığı hutbeler bu tür meselelerin dışında genellikle kişinin iyi bir Müslüman olması yönünde telkinler içeren metinler olduğu görülmüştür (Arıcı 2014; Yalçın 2014; Sezer 2014). Ayrıca Mersin İl Müftülüğü'nün hazırladığı ve Adana camilerinde okutulan Cuma hutbesi de "Çanakkale ve Milli Şuur" ilişkisi temelinde "birlikte yaşama" konusunu ele almıştır (Metin 2014).

Araştırmada Adana İli Büyükdikili Mahallesi Camii'ne 22.11.2013-21.08.2015 tarihleri arasında gönderilen, DİB ve Din Hizmetleri Genel Müdürlügü (63), Adana İl Müftülüğü (23) ve Mersin İl Müftülüğü'nün (1) hazırlamış olduğu 87 hutbe incelenmiştir. Bu hutbelerin 63 tanesi DİB'in merkezi kurumu olan DHGM tarafından hazırlanmış ve Türkiye'deki tüm camilerde okutulmuştur. Geriye kalan 24 hutbenin ise 23 tanesi Adana İl Müftülüğü, 1 tanesi de Mersin İl Müftülüğü tarafından hazırlanmıştır. Mersin İl Müftülüğü tarafından hazırlanan hutbenin Adana camilerinde okutulmasının nedeni, bir tür kurumlar arası iş birliği olarak görülebilir. Çünkü merkezden hutbe gönderilmediğinde taşradaki teşkilatların bu tür yardımlaşmaları, görülen olağan bir durumdur. Ayrıca Büyükdikili Mahallesi Camii'nin seçilmesi, Adana'daki diğer camiler de göz önünde tutulduğunda, araştırmanın metodolojisi anlamında ayrı bir önem teşkil etmemektedir. Çünkü bu dönemde kurumsal olarak Adana Müftülüğü'ne bağlı tüm camilerde, Cuma ve bayram namazlarında aynı hutbeler okutulmuştur. Araştırmada analiz edilen hutbelerin Büyükdikili Camii'nden temin edilmesinin nedeni, cami görevlisi imamın bu dönemdeki hutbe dokümanlarını arşivlemesiyle ilgilidir.

Araştırmanın yöntemini, ele aldığı konular çerçevesinde hutbelerin söylem analizi oluşturmaktadır. Toplumun gündemini meşgul eden çeşitli siyasal, sosyal ve dini konuların "birlikte yaşama" ahlakını ve kültürünü tesis etmesinde, hutbelerin yaklaşımı ve ürettiği söylem analiz edilecektir. Söylem analizi, bir doküman olarak hutbeler üzerinden okunmaya çalışılacaktır. Zira dokümanlar nitel araştırmalarda kullanılan önemli bilgi kaynaklarından olmakla birlikte araştırmacı, ihtiyacı olan veriyi gözlem veya görüşme yapmadan da edinebilir (Yıldırım- Şimşek 2013: 218). Çünkü doküman incelemesi, araştırılması planlanan konu, olgu veya sorunsal ile ilgili bilgileri içeren yazılı materyallerin analizini içermektedir (Yıldırım-Şimşek 2013: 217). Doküman incelemesi, genellikle tarih, dilbilim ve arkeolojide kullanılsa da, sosyolojide de kullanılan bir yöntemdir. Özellikle Marx ve Engels'in İngiltere' de işçi sınıfı incelerken fabrika denetim raporlarından önemli bilgiler elde etmesi, Durkheim'in intihar konusunu araştırırken resmi belgelerden faydalanması ve Weber'in Protestan mezhebi ve kapitalizm ilişkisini ele aldığı önemli çalışmasında, dini dokümanları ve mezheplere ait küçük not ve ilanları kullanması, doküman inceleme tekniğinin önemli örneklerini oluşturmaktadır (Forster 1994). Doküman incelemesi, analiz konusu temelinde 
örneklem seçme, kategorilerin geliştirilmesi ve analiz biriminin saptanması aşamalarında oluşmaktadır. Bu çalışma kapsamında doküman incelemesi, "birlikte yaşama" temalı hutbe metinlerinin ya da konusu farklı olsa dahi bu hutbe metinlerinde geçen "birlikte yaşama" söyleminin yer aldığı hutbeler seçilerek bir örneklem oluşturulmuş, örneklemdeki hutbelerin "birlikte yaşama" konusunu hangi bağlamlarda ele aldıkları belirlenmiş, sonrasinda ise dokuman incelemesinde bir analiz birimi olan "tema" üzerinden bu hutbelerin "birlikte yaşama" temalarının söylem analizlerinin saptanmasına geçilmiştir.

\section{HUTBELERIN “BIRLIKTE YAŞAMA” SÖYLEMLERI}

Hutbelerin söylem analizleri; "birlikte yaşamanın dini referansları", "birlikte var olmanın tarihsel kodu ve Çanakkale ruhu", "ensar-muhacir söylemiyle birlikte yaşamayı inşa edebilmek", "fitne ve kaos: birlikte yaşamanın cellatları" ve "birlikte yaşamanın umudu: Türkiye" başlıkları altında ele alınacaktır. Hutbelerden yapılan alıntılarla, Diyanet İşleri Başkanlığı'nın birlikte yaşama kültürü ve ahlakını hangi zeminde ele aldığı, birlikte yaşama ahlakının kültürel ve tarihsel boyutları, gündelik yaşam pratiklerinde uygulama önerileri, birlikte yaşamanın söylemlerinin ve referanslarının neler olduğu vs. değerlendirilecektir.

\section{Birlikte Yaşamanın Dini Referansları}

Günümüz toplumlarında "etnik, dini, mezhebi ve meşrebi farklılıklar, bazen çatışma nedeni olarak görülebiliyor" (DHGM 2015f). Savaş, suç, göç, katliam, terör, ekonomik kriz, küreselleşme, kalıplaşmış düşünceler ve daha birçok makro/mikro sebepler, bu ayrışma ve çatışmayı körüklemektedir. Bu çatışmaların Batı'nın müdahalesinden sonra Müslüman coğrafyalarda yaşanmaya başlaması, Batı medeniyetinin onto-epistemik iddiasına da ters düşmektedir. "Bugün bazı Batı toplumlarında Müslümanlara karşı nefret söylemleri, ayrımcılık politikaları gibi birlikte yaşamayı zedeleyen olumsuzluklar görülmektedir. Maalesef kimi İslam toplumlarında da mezhepçilik, meşrepçilik, rrkçılık, ideolojik ayrımcılık sebebiyle iç çatışmalar yaşanmaktadır." (DHGM 2015e).

Hutbelerde farklılıkların insan doğasından kaynaklı bir durum olduğu, ayetlerden verilen örneklerle desteklenmektedir. "Göklerin ve yerin yaratılması, dillerinizin ve renklerinizin farklılığı O'nun ayetlerindendir. Şüphesiz ki bunda bilginler için ayetler vardır" (Rum 30/22), "Ey İnsanlar! Sizleri bir erkek ve bir dişiden yarattık ve 'tanışasınız' diye sizleri milletlere ve kabilelere ayırdık. Allah katında en üstün olanınız ise, en çok sakınanızdır.." (Hucurat 49/13). İslam inanç esaslarına göre bir kişinin dilinin, renginin, cinsiyetinin, etnik yapısının farklı olması, ayrıca sınıf, statü, muhatap alınma ve diğer tüm kategorileştirme anlamındaki farklılıklar, diğer insanlardan aşağı ya da üst bir mertebede olması anlamına gelmemektedir. Bilakis bu durumun bir ayırt edicilik, ayrımcıllk, ötekileştirme, sinıflaştırma veya nesneleştirme davranışının aksine farklılıkların birer zenginlik olduğu vurgulanmaktadır. Ayrıca Hz. Muhammed'in Veda Hutbesi'nde de “Hepiniz Adem'in çocuklarısınız. Adem ise topraktandır. Arap'ın Arap olmayana, Arap olmayanın da Arap üzerine üstünlüğü olmadığı gibi, kırmızı tenlinin siyah üzerine siyahın da kırmızı tenli üzerinde bir üstünlüğü yoktur. Üstünlük ancak takvada, Allah'tan korkmaktadır" (www.vedahutbesi.gen.tr) şeklindeki sözleri, ayetleri destekleyecek niteliktedir. Bununla birlikte ilk İslam toplumunun şekillenişinde Hz. Peygamber'in çevresindeki Müslümanlara bakıldığında da, Bilal-i Habeşi, Selmani Farisi gibi birçok sahabenin farklı etnik yapıya mensup olması, İslam inancının yaşam pratiklerinin farklılıkları birer zenginlik olarak gördügünü göstermektedir. 
Hutbelerde etnik ve soy ayrımcılığı yapmak, farklılıkları küçük ve hakir görmek cahiliye dönemi (İslam dini gönderilmeden önceki Mekke Kureyş toplumu) adetleri olarak ifade edilmektedir. "Cahiliye döneminde insanlar etnik kökeni, mensup oldukları kavim ve kabileleriyle övünürlerdi. Haksız da olsa kabilesini savunur, kendilerini başkalarından üstün görürlerdi. Irk ve renginden dolayı insanlar hor ve hakir görülür, toplumdan dışlanır ve aşağılanırdı" (DHGM 2015h). Zira İslam dinini kabul eden ilk kişilerin çoğunlukla köle, siyahi, geliri düşük, soylu aileden gelmemesi gibi nedenlerden dolayı Mekke'nin seçkinleri hem bu dini kabul edenleri hem de İslam dinini küçümsemişlerdi. Bundan dolayı asr-1 saadet olarak İslam Tarihi'nde geçen bu dönem, hutbelerde birlikte yaşama konusu ele alınırken sıklıkla referans gösterilmektedir. Çünkü bu dönemde toplum, önemli bir toplumsal değişime uğramış, İslam dini adeta gündelik yaşamı yeniden düzenleyerek tüm sosyal ilişkileri, yaşam biçimini ve toplumsal kurumları önemli ölçüde etkilemiştir. DHGM'nin hazırladığı hutbede de bu hususa değinilmiştir: "Alemlerin rahmet kaynağı Efendimiz (s.a.s.), asabiyet ve cehaletin, bağnazlığın, kör taassubun zincirlerini kırarak; dilleri, renkleri, gelenek ve görenekleri farklı olmasına rağmen 'iyilik ve takvada yardımlaşanlardan' bütün insanlığa örnek bir kardeşlik toplumu inşa etti" (DHGM 2015p). Böylece bu toplumun "etnik, siyasi, mezhep ve meşrep farklılığ bir ayrıllk ve fitne unsuru değil önemli bir zenginlik kaynağı oldu” (DHGM 2015p).

Hutbelerde İslam dininin farklılıkları Allah'ın bir ayeti olarak gördüğü, insanın hangi dine, dile, etnik yapıya, milliyete, cinsiyete sahip olursa olsun can, namus, şeref, onur ve haysiyetinin dokunulmazlığına değinilmektedir. Birlikte yaşamanın formülü, "farklılıkları çatışma ve yıkım sebebi değil, ilahi kudretin delili olarak görebilmekten geçer." (DHGM 2015e). Ayrıca insan, "rengi, dili, rrkı, cinsiyeti fark etmeksizin insan olmakla her türlü dokunulmazlık hakkına doğuştan kavuşandır. Canı özgedir; ırzı, şerefi, haysiyeti, onuru, namusu her türlü değerin üstündedir." (DİB 2015a).

Doğusuyla batısıyla, kuzeyiyle güneyiyle insanlık olarak hepimiz büyük bir aileyiz. Hz. Adem ile Havva'nın çocuklarıyı... Her insan saygındır, mükerremdir, özeldir. Dili, rengi, cinsiyeti ve milliyeti ne olursa olsun her insanın cant, haysiyeti ve malı dokunulmazdır. (DHGM 2015f).

"Hz. Peygamber ve Birlikte Yaşama Ahlakı" başlıklı Cuma hutbesinde, İslam dininin din, dil, ırk, mezhep ayrımı göz etmeksizin insanların ve toplumların bir arada yaşamasına imkan veren bir din olduğu ve Peygamber efendimizin sünnet ve hadislerinde de bir arada yaşama imkanını tesis edecek söz ve davranışların bulunduğu ifade edilmektedir (Bkz. DHGM 2015e). Öte yandan hutbeler, birlikte yaşama ahlakını sadece bilinçlerde inşa etmeyi değil aynı zamanda bu kültürün eyleme dönüşmesi anlamında da telkinlerde bulunmaktadır. "Farklı ırk, dil ve renkte yaratılmışlığımızı Allah'ın ayeti olarak görelim. Gelin tüm ırkçılığı, mezhepçiliği kaldırıp atarak birlik ve kardeşliğe hicret edelim." (DHGM 2014c).

Hutbelerde insanın her şeyden daha değerli ve önemli olduğu sıklıkla vurgulanmakta ve hiçbir beşeri sistemin veya düşüncenin insanın yaşama hakkından üstün olmadığ belirtilmektedir. Bu insan merkezli düşüncenin temel referansı olarak İslam dini gösterilmektedir. "Bizler bir insanı yaşatmanın bütün insanlığa can vermek olduğunu bildiren, insanları yok etmek değil, yaşatmakla mükellef kıldıran, bir dinin müntesipleriyiz... İnandığımız bütün değerler bize gösteriyor ki hiçbir dünyevi hırs, çıkar ve ideoloji, bir insanı yaşatmaktan daha değerli olamaz" (DHGM 2015p). Diyanet İşleri Başkanlığı'nın, hazırladığı hutbelerdeki, insanın değeri, yaşam hakkı, can, mal, namus dokunulmazlı̆̆ gibi üst değerleri İslam dinini referans göstererek ifade etmesi, esasında sadece İslam inanç 
esaslarını ortaya koyarak itikadi bir duruma dikkat çekme niyetinden fazlaca bir şeydir. Aynı zamanda birlikte yaşama ve insana verilen kıymetin güçlü bir şekilde İslam referansıyla sunulması, küresel dolaşımda olan Müslümanları terörle eşleştirme, İslamafobia çabaları, şiddeti yöntem olarak belirlemiş sapkın dini mezheplerin vukuatlarına da bir yanıt niteliğindedir.

Camilerde okutulan "ibadet", "dini ve milli gün ve geceler", "ahlak" ve "inanç" konulu hutbelerde her ne kadar konu doğrudan dini bir eylem/içerik olsa da, bu eylemin/içeriğin birlikte yaşama kültürüne referans eden toplumsal boyutlarına da değinilmiştir. Örneğin 2013 yılı Kurban Bayramı́nın öncesinde okutulan Cuma Hutbesi'nde, kurbanın dünyevileşmeye karşı ilahi bir uyarı olduğu ve modern hayata, bireyciliğe ve benmerkezciliğe karşı bir duruşu simgelediği vurgulanarak Hobbes'un düşüncesine telmihle, kurbanın "insan insanın cennetidir" inancına götüren bir ibadet olduğunun altı çizilmiştir. Böylece kurban ibadetinin, "hiçbir etnik, dini ve mezhepsel fark gözetilmeksizin kardeş̧̧e yaşamamız gerektiği inancını salık veren bir ibadet” (DHGM 2013b) olduğuna dikkat çekilmiştir.

\section{Birlikte Var olmanın Tarihsel Kodu ve Çanakkale Ruhu}

Hutbelerde tarihin bir arada yaşama tecrübesine çokça göndermede bulunulur. Anadolu'nun binlerce yıl kültürlere, milletlere ve inançlara ev sahipliği yapması, bundan sonra da farklılıkların birlikte yaşayabileceğinin bir göstergesi olarak sunulur. $\mathrm{Bu}$ toprakların sevgi, saygı, hoşgörü, yardımlaşma gibi hasletlerle yoğrulduğu ve Anadolu kültürünün bu harçlarla medeniyetleri inşa ettiği vurgulanır.

Asırlar boyu, başta Anadolu olmak üzere, İslam coğrafyasında farklı din, dil, ırk, mezhep ve meşrep mensupları temel hak ve hürriyetlere saygı temelinde, güven içerisinde bir arada yaşadı. Engin hoşgörü, sevgi, saygl, paylaşma, yardımlaşma, güvenme ve güven verme gibi insani meziyetlerin pek çoğu bu medeniyette görüldü (DHGM 2015e).

Hutbelerde yer yer birlikte yaşamanın kodu olarak tarihten örnek olaylar gösterilmektedir. Bu metinlerde dinleyicilere genel olarak "birlikte yaşayabilirsek, birlikte var oluruz" mesajı verilir. Çünkü günümüz İslam toplumlarında kardeşliği zedeleyen birçok unsurun başında "herkesin kendini, kendi düşüncesini, mezhebini, meşrebini, benliğini hakikatin yerine koyması" (DHGM 2014a) gelmektedir. Dolayısıla hutbelerde toplumsal hafızayı diri tutacak, birlik ve beraberliğin timsali olayları hatırlatmak, birlikte yaşamanın da kodlarını hatırlatacaktır. Böylelikle Osmanlı Devleti'ni işgale yeltenen Batı ülkelerine, İslam Coğrafyasının hemen her yerinden gelerek Çanakkale'de karşı koyan Müslümanlar, metinlerde birlikte var olmak için direnmenin örnekliği olarak karşımıza çıkmaktadır. "Çanakkale Ruhu" olarak adlandırılan bu bilinç, farklı etnik yapıdan, kültürden, coğrafyadan olsalar da farklı dili konuşsalar da yüzyıllardır bir arada yaşamanın ve aynı amaç uğruna bir araya gelmenin adı olarak izah edilmiştir. Örneğin Mersin İli Müftülüğü'nce hazırlanan "Çanakkale ve Milli Şuur" başlıklı Cuma hutbesinde, Çanakkale'deki vatan savunmasının milli bir bilinç oluşturduğunu ve tüm farklılıklara rağmen birlik ve beraberlik içerisinde herkesin vatanı savunmak için omuz omuza savaştığı anlatılmaktadır. Ayrıca oluşan bu "Çanakkale Ruhu"nun bugün de devam etmesi gerektiği ve "bizi bölmeye ve parçalamaya çalışanlara" karşı sağlam bir iradeyle karşı konulması gerektiğinin altı çizilmiştir (Metin 2014). Bunun yanı sıra "bu vatanı bölmek ve ele geçirmek için haince plan hazırlayanların her zaman var olduklarını" ve bundan sonra da var olacaklarının unutulmaması gerektiği telkin edilmiştir (Metin 2014). Çanakkale şehitlerini

SEFAD, 2017 (38): 507-532 
konu alan bir başka hutbede, Çanakkale'de savaşan Müslümanların Şam'dan, Bağdat'tan, Filistin'den, Beyrut'tan, Saraybosna ve diğer birçok İslam beldelerinden geldikleri; dilleri, ırkları, kavimleri farklı olsa da aynı ideal, duygu ve gayreti taşıdıkları üzerinde durulmuş ve böylelikle esasında Müslümanların birçok farklılıklarına rağmen özünde kardeş oldukları "Çanakkale Ruhu" temelinde anlatılmaya çalışılmaktadır (DHGM 2015c).

Hutbelerde "birlikte yaşama" kavramı, genellikle ilk anlamıla ele alınmakla beraber "birlikte yaşama"yla daha çok İslam toplumlarındaki "bir arada yaşama" kastedilmektedir. Metinlerde günümüz sosyal bilimlerinin konusunu oluşturan Taylor (2010), Habermas (2010), Kymlicka (1998; 2001), Parekh (2002) ve Wolf (2010) gibi, çokkültürlülüğü birlikte yaşamanın bir modeli olarak sunma üzerinden gerçekleşen tartışmaların uzağında bir birlikte yaşama jargonu kullanılmaktadır. Hutbelerde İslam kardeşliği temelinde işlenen "birlikte yaşama", bu yönüyle hutbelerin evrensel mesaj verebilmesinin de önüne geçmektedir. Kuşkusuz İslam toplumlarında yaşanan bölünme, kamplaşma, mezhepleşme, ayrımcılık, iç savaş, terör vs. gibi olaylar, hutbelerin hedef kitlesi olan Türkiye Müslümanlarına telkinleri içerse de ve bu amacı ziyadesiyle yerine getirse de, hutbelerin evrensel boyutunun da göz ardı edilmemesi gerekmektedir.

\section{Ensar-Muhacir Söylemiyle Birlikte Yaşamayı İnşa Edebilmek}

Yaklaşık altı yıldan bu yana devam eden Suriye İç Savaşı ve sonrasında diğer ülkelere, en çok da Türkiye'ye gelen sığınmacılar, toplumumuzun neredeyse Cumhuriyet'in kuruluşundan bu yana karşı karşıya kaldığı en büyük göç dalgalarından birini oluşturmaktadır. Kısa sürede ve hızla gelişen bu göç dalgasına karşın Türkiye hazırlıksız yakalanmış, toplumumuz ise bu yeni durumu nasıl karşılaması gerektiğine yönelik zihinsel karmaşalar yaşamıştır. Kuşkusuz Türkiye toplumunun büyük çoğunluğu Suriyeli sığınmacılara kucak açmışlardır. Zira zaman içerisinde ve hala çeşitli vesilelerle tartışmaya açılan Suriyeliler meselesi (son olarak Sakarya'da hamile bir Suriyeli annenin çocuğuyla birlikte katledilmesiyle gündeme oturan), toplumda korku ve kaos oluşturma potansiyeline de sahip bir meseledir. Dolayısıyla Suriyeli sığınmacılar ve toplumun bu sığınmacılara yönelik verdiği tepkilerden kaynaklanan mevcut problemler göz ardı edilmemelidir, ancak bu hususta asparagas haberler ve hatalı bilgilendirmelerle toplumu kutuplaştırmanın da bir faydası olmayacaktır. Bu konjonktür bağlamında Diyanet İşleri Başkanlığı'nın hutbelerde ensar-muhacir söylemini geliştirmesi ve Mekke-Medine Müslümanlarına telmihle, toplumsal hafızayı Hz. Peygamber örnekliğinde topluma aktarımı, Suriyeli sığınmacılar ve diğer unsurlarla birlikte yaşama konusunda oldukça olumlu bir strateji olarak görülmektedir.

Âlemlere rahmet olarak gönderilen Efendimiz (s.a.s)'in bizlere takdim ettiği en önemli değerlerden biri şüphesiz kardeşliktir. Bu kardeşlik, dilleri, renkleri, ırkları, coğrafyaları farklı olmakla beraber; inançları, sevinçleri, hüzünleri, idealleri ve umutları bir olanları birbirine sımsıkı kenetleyen iman kardeşliğidir. Bu kardeşlikte birlik ve beraberliği, onur ve haysiyeti zedeleyen mezhep, meşrep, cehalet ve asabiyete asla yer yoktur. Bu kardeşlikte cana, mala, insan hayatına kastetmek kesinlikle yoktur. Bu kardeşlik, üstünlük yarışın, ötekileştirmeyi, ezmeyi, yok saymayı mubah gören bir kardeşlik değildir (DHGM 2015r).

Mezhep, meşrep, ırk, bölge ve coğrafya farklarm değil, sadece ve sadece Efendimiz (s.a.s)'in Ensar ve Muhacir arasinda tesis ettiği 'ben'i 'biz', 'biz'i 'bir' yapan İslam kardeşliğini ön plana çıarmalıyız (DHGM 2015k). 
...Bize 'Ensar' diye sarlan misafirlerimiz bizi Medine-i Münevvere'nin sakinlerine denk tutmuşlardır. Ensar'in en büyüklerinden Rasulullah'ı evinde misafir eden Ebu Eyyub elEnsari'yi bağrına basan bu aziz millet kendisine el açıp sı̆̆ınan kimseleri dışlayıp onları düşmanına teslim edemezdi (Çelik 2014).

Hutbelerdeki kardeşlik vurgusu, mezhep, meşrep, ırk ve diğer farklılıklara rağmen İslam kardeşliği temelinde sunulmaktadır. Metinlerde geçen "Mü'minler ancak kardeştirler" (Hucurat 49/10) ayeti sıklıkla hatırlatılmakta ve böylelikle toplumda İslam kardeşliği üzerinden aidiyet, kimlik, yardımlaşma, güven ve birlikte yaşama duygusu gibi sosyal sermaye (social capital) öğeleri tesis edilmeye çalışılmaktadır. ${ }^{2}$ Bayram hutbelerinde ensarmuhacir söyleminin, empati kurma yöntemiyle daha çok işlenmesinin yanı sıra özellikle Ramazan ayı boyunca okutulan hutbelerde yardımlaşma ve dayanışma duygularına yoğun biçimde dikkat çekildiği görülmektedir. Zira yardımlaşma, Müslümanların birliği ve dirliğini sağlamada, ayrıca sınırları ortadan kaldırarak gönül köprüleri kurmada önemli araçlardan biri olarak değerlendirilir. Ramazan ayında DHGM'nin hazırladı̆̆ı bir hutbede Müslüman bireyin, kendisine, Rabbine, ailesine, yoksullara, kimsesizlere, mültecilere, yetimlere, yaşlilara ve bütün mahlukata iyilik yapmasının ögüutlendiği (DHGM 2015i) görülmektedir. Öte yandan 2015 yılı Ramazan Bayramı hutbesinde, bayramın yardımseverlerin bayramı olduğuna yönelik ibarede, mültecilere yönelik yardımseverlik de övülmektedir. "Bugün, yoksula, yetime, kimsesize, çaresize, güçsüze, garibe, mülteci kardeşlerimize karşı sorumluluk hissetmenin" (DHGM 2015n) bayramı olduğu vurgulanmaktadir.

Aziz Kardeşlerim! Bütün Müslümanların sevinci demek olan bu bayramda çeşitli sebeplerle zulme uğrayan, yurtlarını terke mecbur bırakılan Suriyeli kardeşlerimiz için neler yapıyoruz? Ülkemize sı̆̆ınan bu muhacirlere ne kadar Ensar olabiliyoruz? Dünyanın farkl yerlerinde pek çok kardeşimiz baskl, zulüm, şiddet ve ölüm esaretindeyken 'Acaba bizim bayram yapmaya hakkımız var mı?' diye düşünmeden edemiyoruz (Yılmaz, 2013).

Nasıl Bir Kardeşlik? başlıklı Cuma hutbesinde Ensar ve muhacir ilişkilerine atıfta bulunularak Peygamberimizin dilleri, renkleri, gelenek ve görenekleri farklı olmasına rağmen "iyilik ve takvada yardımlaşan" insanlardan örnek bir toplum inşa edildiğine vurgu yapılmıştır (DHGM 2014a). Bu bağlamda hutbelerde savaştan kaçarak Türkiye'ye sı̆̆ınan Suriyelilere yönelik yardım yapılması telkin edilirken, insanlara bu sığınmacılara bir "Ensar" gibi davranmaları sıklıkla tavsiye edilmektedir (Adana Müftülüğü İrşad Kurulu 2015).

Şiddetten, savaştan, ölümden kaçarken evinden ayr düşmüş milyonlarca kardeşimiz var. Suriye'den ülkemize gelen bir milyonu aşkın mülteci bulunmaktadır. Onlar bizim muhacirlerimizdir. Bize düşen onlara Ensar olmak, gönül kapılarımızı açıp el uzatmaktır. Zira Müslümanın ahlakı, kimseyi kimsesiz bırakmamak, ihtiyaç sahiplerinin ihtiyacın gidermektir (DHGM 2014b).

Şiddetin, savaşın, açlı̆̆ın sardığı ülkelerde çok sayıda çocuk yetim kalmaktadır... Yetimler, öksüzler ümmetin Enes'i, Beşir'i, Abdullah'ıdır. Yetimler-kimsesizler, bizler için bir yük değil bir

\footnotetext{
2 Sosyal sermaye, sosyal kurumların örgütlenmiş eylemlerini kolaylaştırmada toplumun etkinliğini arttıran güven, normlar ve iletişim ağlarının önemli etkileridir (Putnam 1993: 169). Fukuyama (2009: 34) sosyal sermayeyi, "bir grubun üyelerinin paylaştıkları ve bu kişilerin işbirliği yapmalarına imkan tanıyan gayr-i resmi değerler ve normlar kümesi olarak" tanımlamaktadır. Ayrıca sosyal sermaye, bir toplumda güven duygusunun hakim olmasından neşet eden bir yetidir. Millet gibi geniş gruplarla aile gibi toplumun en küçük ve temel sosyal grupları arasındaki tüm grupların içselleştirdikleri bir haslettir (Can 2015: 46).
} 
bereket vesilesidir. Bu yavrularmız, bize Allah Resulü (s.a.s)'nün birer emanetidir (DHGM 2014b).

Savaş dolayısıyla yerlerinden edilen insanların dramları da hutbelerin konusunu teşkil etmektedir. Açlık, yoksulluk, facialar, hastalık ve daha birçok olumsuz koşullara değinilmektedir. Bu bağlamda (incelenen hutbeler bu olaylar öncesi döneme ait olsa da) geçtiğimiz yıllarda sahile vuran Aylan bebeğin cesedi, Ümran adlı Suriyeli çocuğun bombalara maruz kalmış bedenine şaşkınlıkla bakışı ve Avrupa'ya yasadışı yollarla geçmek isteyen sı̆̆ınmacıların yüzlercesinin sulara gömülen bedenleri, hutbelerin konularını oluşturmaktadır. Örneğin yetimleri koruma ve kollama gereksinimi ve göçmen faciaları ile ilgili Cuma Hutbelerinde şu ifadeler yer almaktadır:

Şiddet, günümüzde coğrafya, din, dil, ırk ve sosyal statü tanımaksızın bütün insanlığı tehdit eden bir boyutta yaşanmaktadır. Ne yazık ki bu tehdidi en ağır biçimde yaşayanlar kadınlar ve çocuklar olmaktadır (DİB 2015b).

Yetimler, önceliklidir. Çünkü onlar, bizlere Allah'ın birer emanetidir. Bu çocukların bazısı şehit çocuklarıdır, bazısı annesini ya da babasını hastalığa, kazaya kurban vermiştir. Kimileri de daha çocukluklarını yaşayamadan şehirleri yıktığı kadar ruhları ve yarınları da yıkan savaşın soğuk yüzüyle karşılaşmıştır. Yerlerinden, yurtlarından, aile sıcaklığından mahrum kalmışlardır...Onlar himaye edilmeyi herkesten çok hak ederler (DHGM 2015m).

Son zamanlarda sıkça yaşanan göçmen facialarına birkaç gün önce bir yenisi daha eklendi. Bu elim olayda, ülkelerindeki yokluk, yoksulluk, açlık ve sefaletten, insan onur ve haysiyetiyle bağdaşmayan uygulamalardan kaçan yüzlerce kişi umutlarıla beraber suların derinliklerine gömüldü... Bu olay, bizlere birlikte yaşama ahlakımızı, insana bakışımızı, sorumluluğumuzu bir kez daha sorgulamamız gerektiğini hatırlattı (DHGM 2015g).

\section{Fitne ve Kaos: Birlikte Yaşamanın Cellatları}

Türkiye' de yaklaşık son beş yılda yaşanan Suriye iç savaşı, sığınmacıların Türkiye'ye gelişi, Gezi Parkı, 17-25 Aralık, yerel seçimler, cumhurbaşkanlığı ve genel seçimler ve son olarak da 15 Temmuz 2016'da gerçekleşen darbe teşebbüsü ve sonrasında yaşananlar, şüphesiz toplumda siyasal ve sosyal kırılmalar oluşturdu. Siyasal gerilimlerin azami düzeye çıktığı bu dönemlerde toplum, kitlesel hareketlerin oluşmasına daha açık hale geldi. PKK, IŞID, FETÖ/PDY ve DHKP-C gibi terör örgütlerinin silahlı ya da bombalı eylemlerle veya bu terör örgütü sempatizanlarının çeşitli kanallardan, özellikle sosyal medya üzerinden toplumsal ayrışmaları körüklemesi, hutbelerde sıklıkla "fitne, fesat ve kaos" uyarılarının yapılmasını da beraberinde getirdi. Kaldı ki hutbelerin konusu farklılaşsa da, hemen her hutbede "fitne, fesat, kaos, huzursuzluk ortamı"nın oluşturmak isteyenlere karşı uyanık olmak ve kardeşliğin, birlik ve beraberliğin, ülfet ve muhabbetin tesis edilmesi gerektiği telkin edilmektedir. Böylelikle iftiraların, asılsız söz ve ithamların, yalan ve çirkin sözlerin iletişim araçlarıyla özellikle merak ve ilgi uyandıracak tarzda sunulmasına ve bu yöntemin adeta bir dedikodu faaliyeti olarak tedavüle sürülmesine dikkat çekilmektedir. Bu hutbelere göre, bireyin ve toplumun din ve ahlak anlayışlarında büyük ölçüde hasara yol açan bu faaliyetler, son yılların önemli bir iletişim aracı olan sosyal medyada arzı endam etmektedir (DHGM 2014e).

Özellikle sosyal paylaşım sitelerinde yayınlanan bir haber, milyonlar etkileyebilmekte, kitleleri tesir altına alabilmektedir. Kimileri bilgisayar başında, ilahi gözetim altında oldukların unutarak kişilerin haysiyetini, şerefini zedeleyecek sorumsuz tutumlar sergileyebilmektedirler. Böylece, bir 
taraftan kul hakkına, diğer taraftan da toplumda infiale neden olarak kamu hakkına girmektedirler (DHGM 2014e).

Adana İl müftülüğünün hazırladığı hutbede, Kur'an-1 Kerim'e referansla, adam öldürmekten daha büyük bir günah olarak nitelendirilen fitne, "genelde insanlar arasinda kargaşa çıkarmak ve toplumda anarşik olayların oluşmasına sebep olan tüm kötü söz, tutum ve davranışlar" (Aydoğan 2013) olarak tanımlanmıştır. Ayrıca fitnenin, ortaya çıktığı yerlerde toplumun parçalanıp yok olmasına, toplumdaki anarşi olayları sonucunda kan dökülmesi neden olduğunun altı çizilmiştir. Bununla birlikte fitnenin giderek küresel bir yıkıma dönüşeceğine değinilerek, insanların, ailelerin, toplumların ve hatta ülkelerin birbirleri arasında önü alınamayan problemlerin ortaya çıkmasına da aracılık edebileceğine (Aydoğan 2013) dikkat çekilmiştir.

Bugün İslam kardeşliğinin önündeki en büyük engellerden biri ırkçıllk ve ayrımcllık zihniyetidir.

Bu zihniyet, bazen kendi ırkını, soyunu, kabilesini, rengini üstün görme şeklinde tezahür etmektedir. Bazen de kendi mezhebini, meşrebini, ideolojisini üstün görme şeklinde ortaya çıkmaktadır. Bu anlayış, dostluk ve kardeşliğin yerine kin ve nefreti, adalet ve merhametin yerine zulüm ve haksızlı̆̆l, birlik ve beraberliğin yerine tefrika ve ayrımcllğgl getirir (DHGM 2015h).

Metinlerde fitne ve kaos konusunun birçok tarihi olayın yanı sıra Kerbela Olayı örneğinde de ele alındığı görülmektedir. Çünkü Kerbela, Hz. Hüseyin'in şehit edildiği yer ve olay olarak tarihte yerini almaktadır. Ayrıca bu olayda ölen ve öldüren tarafın da Müslüman olması, fitnenin ne denli büyük yıkımlara sebep olabileceğini ortaya koymaktadır. Örneğin "Muharrem Ayı ve Kerbela" konulu hutbede, Kerbela Olayı'nın ve Hz. Hüseyin'in ve yetmişten fazla müminin şehit edilmesinin doğru okunması ve anlaşılması gerektiği üzerinde durulmaktadır. Bu olayın kin, nefret, ayrışma ve bölünmeye değil birlik-beraberlik, sevgi, sayg1, muhabbet ve hoşgörüye dönüştürülmesi gerektiği üzerinde durulmaktadır (DHGM 2013a). Ayrıca hutbelerde Muharrem ayının Müslümanlar için, kardeşlik ve beraberlik şuurlarının güçlenmesine vesile olması gerektiği vurgulanırken, geçmişin acılarını yeniden yaşatmak, gönüllerde kapanmaz yaralar açmak, ortak değerleri ayrılığa, kin ve nefrete dönüştürmek isteyenlere karşı "tek yürek" halinde karşı koyma telkin edilmiştir (DGHM 2013a; 2014d).

Ancak üzülerek şahit oluyoruz ki son yillarda yaşanan olaylar mezhebi, meşrebi ne olursa olsun İslam toplumunun Kerbela'yı, Hz. Hüseyin ve arkadaşların hala doğru okumadı̆̆ını, doğru anlamadığını ortaya koyuyor. Onun içindir ki bugün etrafımızda nice Kerbelalar yaşanıyor. Bağdat'tan, Şam'dan, Kahire'den, İslamabad'dan ateşler her gün yükseliyor. Sadece Irak'ta ayda ortalama bin insan can veriyor... Milyonlarca insan yerinden, yurdundan, evinden barkindan oldu. Çocuklar umutlarm, hayallerini, geleceklerini yitirdi...Kardeşlerim! Yeni Kerbelaların yaşanmaması için ortak bir dile ihtiyacımız var. Yüreklerimizi birleştirmeye, gönül kapılarımızı birbirimize açmaya ihtiyactmız var. İşte bu yüzden Muharrem, bizim için ortak bir hüzün mevsimi olduğu kadar adaleti, hikmeti, merhameti, kardeşliği, dostluğu hatırlatan ibret sofrası olmalıdır. Muharremi, Müslümanların kardeşlik ve beraberlik şuurlarının güçlenmesi için bir firsat bilmeliyiz (DHGM 2013a).

Fitne ve fesadın farkında olunduğu, terör ve şiddetle kaos oluşturmak isteyenlerin başarılı olamayacağı, birlik ve beraberliğin sürdürüleceği, kardeşçe bir arada yaşamaya devam edileceği ve gerekirse mukaddes değerler uğruna hayatından vazgeçebileceği mesajı, hutbe metinlerinde yer almaktadır. Çünkü asıl amacın Müslüman coğrafyasında "sevgi,

SEFAD, 2017 (38): 507-532 
merhamet, adalet, barış ve hoşgörüyle insanların hayat bulduğu, onur kazandığı, huzurla yaşadığı topraklar"ın (DİB 2014c) olmasıdır.

Hepimiz hayatımızı etkileyeme çalışan ve yaşadı̆̆ı̆ız topraklar için pek çok tehlikeli emelleri olan kimselerin varllğından haberdarız. Şehitlerimizin kanıyla sulanmış bu topraklara birileri göz dikse, el uzatsa her birimiz sahip olduğumuz bu mukaddes değerler uğruna malmızı, canımızı seve seve vermekten hiç tereddüt etmeyiz (Polat 2014).

Günümüzde "bazı çevrelerce Din-i Mübin-i İslam ve Müslümanlar terör ve şiddetle özdeşleştirilmek istenmektedir. İnsanlarm kalplerine İslam korkusu yerleştirmek amacıyla yüce dinimiz İslam'a ve onun peygamberine karşı organize bir şekilde çok çirkin bir karalama kampanyası yürütülmektedir. Amaç açıktır; İslam'ın yayıllşına ve gelişmesine engel olmak (DHGM 2015b).

Millet olarak bugün bizlere düşen, şehitlerimizin aziz hatırasın ruh ve gönül dünyamızda yaşatmaktır. Onların uğruna canların verdikleri yüce değerlere sahip çımaktır. İhanet içinde olmamaktır. İstiklalimizi korumaktır (DHGM 2015c).

Fitne, korku ve kaos oluşturma niyetinde olan girişimlere karşı, hutbelerde Müslümanların yapması gereken davranışlara da yer verilmekte ve böylelikle toplumda dayanışma, işbirliği, kısacası sosyal sermaye üretimi amaçlanmaktadır. Öncelikle Müslümanların fitne ve kargaşa çıkaranlarla aynı düşüncede ve davranışta olmayacağı vurgulanmaktadır. "Zulmü beslemek, şiddeti haklı göstermek, merhametsizliğe bahane üretmek asla Müslüman kimliği ile bağdaşmaz" (DİB 2015a). Böylece Müslüman bireyin fitne oluşturucu grup ya da örgütlerle arasına mesafe koyması gerektiği ifade edilmiştir. Bununla birlikte "kardeşliğimizi, birlik ve beraberliğimizi bozmak isteyenlere; aramıza fitne, fesat ve nifak tohumu ekmek isteyenlere asla firsat vermemek" (DHGM 2015c), Müslümanların görevleri arasında yer almaktadır. Ayrıca Ramazan Bayramı hutbesinde de, ülkemize ve toplumumuza yönelik tehditlerin birlikte bertaraf edilmesi telkin edilmektedir: “Öylesine kenetlenelim ki birbirimize, bizi bize düşürmek isteyenlerin ümitlerini ebediyen kıralım; ayağımıza dolanan bütün tuzakları hep birlikte bozalım" (DHGM 2015n). Kısacası hutbelerde fitne, fesat, kaos ve korku öğelerinin işlenmesi, birlikte yaşama pratiğinin zarar görmemesi ve özellikle bu tür faaliyetlerin mevcut birlikte yaşama iklimine zarar vermemesi amacı taşımaktadır.

\section{Birlikte Yaşamanın Umudu: Türkiye}

Hutbelerde İslam coğrafyasındaki savaşlara, felaketlere ve zulümlere oldukça sık değinilmektedir (DİB 2014a; 2014b; DHGM 2015a, 2015d). İslam dünyasındaki zulümlerin sebebi olarak ise, dışarıdan gelen saldırılar ve tehditler, kendi içerisinde yaşadığı siyasi mücadeleler, saltanat ve hükümranlık sevdası, güç ve iktidar tutkusu gösterilmektedir (DİB 2014b; 2014c). Türkiye'nin gerek savaştan ve zulümden kaçarak kapısına gelenleri “açık kapı politikası" gibi uygulamalarla topraklarına kabul etmesi, gerekse de Filistin, Irak ve Myanmar gibi farklı din, mezhep, etnik yapıda olanların birlikte yaşamasını devam ettirebilecek politikaları uluslararası platformlarda savunması, hutbelerde Türkiye'yi "birlikte yaşama" pratiğinin umudu olarak göstermektedir. Hutbelerde öncelikle İslam coğrafyasındaki zulümlere sürekli dikkat çekilmesi ve sonrasında Türkiye'nin bir "umut" olarak sunulması, sıklıkla karşılaşılan bir söylemdir. Örneğin Müslüman ülkelerde yaşanan ayrışma, çatışma ve savaş durumuna dikkat çekilen, Adana'daki camilerde okutulan ve Pozantı İlçe Müftüsü Ali H. Çelik'in hazırladığı hutbede, bazı konularda Ramazan ayının Müslümanlarda farkındalık oluşturması gereğinden bahsedilmektedir. "Hiç Kimse Kimsesiz 
Kalmasın" başlığıyla camilere gönderilen hutbenin ilk satırları, Ortadoğu'da ve İslam coğrafyasındaki iç savaşların İslam toplumlarının sinesinde bir yara gibi durduğundan söz etmektedir:

... yanı başımızda kardeşlerimizin çığllkları ve feryatlar yüreğimizi dağlamaktadır. İslam dünyası hiç olmadı̆̆ı kadar ateşler içerisindedir. Müslüman şehirlerden dumanlar yükselmektedir. Bizler top sesleri ile iftar açarken onlar top seslerinin altında can vermektedirler. Zulüm ve gözyaşı Ramazan dinlemiyor... Kardeş, kardeşi öldürmenin zaferini kutluyor. İnsanlı̆̆ı umudu olan İslam coğrafyası bugün acının, sefaletin, kavgalarm adresi olmuştur (Çelik 2014).

Metinler; Suriye, Filistin, Irak, Myanmar ve Müslüman Afrika ülkeleri gibi savaşın, katliamın, açlığın, sefaletin olduğu bu coğrafyalardaki Müslümanların dertleriyle dertlenmeyi, yardım etmeyi, kucak açmayı, yani bir duruş sergilemeyi salık verir. 2014 yılının Ramazan Bayramı Hutbesinde İslam coğrafyasındaki zulümler ve içler acısı durumlara değinilmiştir. "Ramazan bayramı hüzün günüdür. Filistin'de, Gazze'de, Kudüs'te, Suriye'de, Irak'ta, Doğu Türkistan'da, Myanmar'da ve daha birçok İslam beldelerinde" (DİB 2014c) yaşananlar, bu bayram hutbesinin bir bölümünü oluşturmaktadır. Ayrıca hutbelerde Filistin Meselesine de özellikle değinilmektedir. 2014 yılının Ramazan Ayı'nda İsrail'in Gazze'ye yaptı̆̆ı hava saldırılarının gerçekleştiği günlerde hazırlanan "Mazlumların Ümidi Olabilmek" başlıklı hutbede, bu zulme de bilhassa dikkat çekilmiştir (DİB 2014b).

"Unutmayalm ki, zalime destek olmak, zulme sessiz kalmak Müslüman ahlakıyla asla bağdaşmaz....Issail' in Gazze'de, masum insanlara yönelik zalim saldırısı kalplerimizi bir kez daha yaraladı. Ramazan, oruç, iftar, sahur, teravih demeden; kadın, erkek, yaşll, bebek ayrımı göz etmeden kardeşlerimizin üzerine yağdırllan her bomba yüreğimize saplanıyor. Gönüllerimiz kan ă̆lıyor." (DİB 2014b).

Evrensel Müslüman kardeşliği misyonunu yani "ümmet bilincini", Müslüman olmanın yüklediği bir sorumluluk olarak değerlendiren bazı hutbelerde Türkiye, bir "merkez" ülke, bir "anavatan" olarak sunulur.

Bir yılı daha geride bıraktık. Ancak İslam coğrafyasında kan ve gözyaşı hiç dinmedi. İslam diyarlarında katliam, çatı̧ma, açlık, yoksulluk, cehalet, tefrika hiç eksik olmadı. İslam ülkelerinde kardeşin kardeşi öldürmesine, bebeklerin kimyasal silahlarla katledilmesine, küçücük bedenlerin kurşunlara hedef olmasina engel olamadık. Zalimlerin işledikleri cinayetleri ne yazık ki durduramadik (DİB 2013).

Her gün yüzlerce insanın bombalar altında can verdiği bu ülkelerde kin ve düşmanlık tohumlarn atılırken, asırlardır insanlı̆̆a kucak açmış, medeniyetler oluşturmuş bu alicenap ve kadirşinas milletimizin bağrnnda tarihte olduğu gibi bugün de kardeşlik tohumlar yeşermeye devam etmektedir (Çelik 2014).

Hutbelerde İslam Coğrafyasındaki yangın yerlerinden bahsedilirken Türkiye'nin "insanlığın umudu" olduğu çoğunlukla dile getirilir. Örneğin 2013 yılının son Cuma hutbesinde, bu yılın genel bir muhasebesinin yapılması tavsiye edilmektedir. Pek çok sorunun muhasebe yapılması gerekliliğiyle yer aldığı bu hutbede, "Mazlumların gözyaşlarını silebildik mi, yaralarına merhem olabildik mi? Masumları hedef alan her türlü zulme karşı 'dur' diyebildik mi?" sorularının her müminin kendisine sorması gerektiği vurgulanmaktadır (DİB 2013). Hutbenin sonunda Müslümanlardan imanları, itikatları, birlik, beraberlik, kardeşlik ve İslam dünyası için dua edilmesi istenmektedir. Bu duaların 
yer aldığı hutbenin son kısmında, Türkiye ve İslam ülkeleri için, İslam coğrafyasında tutuşturulan fitne ateşinin son bulması için ve İslam dünyasında "milletimize umut bağlayan" Müslümanların umutlarının boşa çıkmaması için de ayrıca dua istenmektedir (DİB 2013).

'Umudumuz sizsiniz' diyerek dualarla bize seslenen bu Müslümanların umudunu boşa çıarmak, Allah'ın umudunu boşa çıkarmak olur. Zira kapımızı çalan misafirin Rahman'ın misafiri olduğunu, onlara hizmetin Allah adına ev sahipliği yapmak olduğunu unutmamak gerekir...Çoğu dul kadın ve çocuklardan oluşan asrımızın muhacirleri bu yangın yerinden kaçı güvenli yerlere gitmek için evini barkın terk etmiş, kapımıza gelmiş, bizi kurtarıcı bilmişlerdir. Biz Müslümanlar olarak bomba ve silahlarla katledilen bu insanlarn feryatlarına, çocuklarm çı̆̆lıklarına kulaklarımızı tıkayamazdık (Çelik 2014).

Dünyaya tarih boyunca umut olmuş ve olmaya devam eden bir milletin çocuklarn olarak bizler, aramızdaki birlik ruhunu ayakta tutarak mazluma, masuma ve mahruma el uzatmaya devam edelim (DİB 2014b).

Metinlerde kullanılan "umut olmak" söyleminin, bazı siyasal, tarihsel/kültürel ve konjonktürel gerekçelere bağlı olarak üretildiği söylenebilir. Bunlardan ilki siyasal olup Türkiye' nin dış politikada İslam dünyasının sorunları konusunda da, diplomasi geliştirmeye çabalamasıdır. Suriye, Filistin, Arakan, Somali, Ortadoğu ve Afrika ülkelerinde yardıma muhtaç Müslümanlara yönelik Türkiye'nin yürüttügü politikanın, "mazlumların umudu olma" söyleminin gelişmesine katkıda bulunduğu iddia edilebilir. İkinci olarak Türkiye'nin Müslüman toplumlarla var olan tarihsel ve kültürel bağıdır. Osmanlı Devleti'nin yaklaşık dört yüz yıl İslam hilafetini temsil etmiş olması, böylelikle hem dini hem de siyasi gücü yüzyıllardır elinde tutması, bu söylemin gelişmesinde etkili olduğu düşünülmektedir. Üçüncü olarak ise Ortadoğu'nun savaşlar, çatışmalar ve çekişmelerle adeta bir yangın yeri olmasından kaynaklı olarak kendi vatanlarından göç etmek zorunda kalanların, Türkiye'ye sığınmış olmalarıdır. Halihazırda tüm bu sebepler ve ortaya çıkan sonuçları da, etnik, din, dil, mezhep, cinsiyet, soy ayrımı yapmadan "birlikte yaşama" kültürünü ve ahlakını tesis etmenin gerekliliğini ortaya koymaktadır.

\section{SONUÇ}

Hutbeler konusunda daha çok ilahiyat alanında çalışmalar yapılmasına karşın sosyoloji, tarih ve siyaset bilimi alanlarında da az da olsa bazı çalışmalara rastlanılmaktadır. Ancak dünyada ve Türkiye'de her hafta milyonlarca kişinin muhatap olduğu hutbeler konusunda literatürdeki çalışmaların yetersiz olduğu ve bu metinlerin birçok disiplin tarafından çalışılması gerektiği anlaşılmaktadır. Bu anlamda hutbeler, içerik ve söylem bakımından, din-toplum ilişkisi, din-siyaset ilişkisi, din-sosyal sermaye ilişkisi, eğitim psikolojisi, karşılaştırmalı hutbe metinleri ve iletişim becerileri gibi birçok açıdan çalışılabilir.

Hutbelerde "birlikte yaşama" kültürü ve ahlakını konu edindiğimiz bu çalışmada, hutbelerin dönemlere göre söylem değişikliğine gittiği, Cumhuriyet tarihinde DỉB'in dönemin siyasal ve sosyal durumlarına göre din ile irtibatlandırılan konularda farklı söylemleri benimsediği ve kuruluş amacına ve kanuna uygun olarak misyonunu sürdürdüğü görülmektedir. Hutbe metinlerini incelediğimiz 2013-2015 yılları arasında da, gelişen siyasal ve sosyal olayların analiz edilerek toplumu bir arada tutacak ve birlikte yaşama pratiğini sürdürecek ya da güçlendirecek metinlerin hazırlanmaya çalışıldığı anlaşılmaktadır. Toplumun gündemini derinden etkileyen büyük olaylar sonrasında, insanları bilgilendirici, bilinçlendirici ve hatta tepkileri absorbe edici hutbe metinlerinin 
hazırlanması, bu açıdan dikkate değer bir husustur. Zira DİB'in toplumun temel dinamiklerini, oluşan olumlu/olumsuz rezervleri ve sosyal sermaye potansiyelini bu yönüyle yönetmeye çalıştığı söylenebilir.

Hutbe metinlerindeki "birlikte yaşama" söylemine bakıldığında ise, birlikte yaşama probleminin genellikle İslam dünyası merkezli bir problem olarak ele alındığı, diğer dinlere mensup olanlar veya herhangi bir dinin dışında başka inançlara sahip olanların birlikte yaşama problemlerine değinilmediği görülmektedir. Kuşkusuz hutbeler, Müslümanların dünya ölçeğindeki problemlerini ele alıp doğrudan Müslümanların karşı karşıya kaldığı sorunlara odaklanmalıdır, ancak bir din olan İslam'ın evrensel mesajını, Müslümanların dışındaki insanları konu edinerek veya bu insanlara hitap ederek de ulaştırmak gerekir. $\mathrm{Bu}$ anlamda hutbelerin "evrensel" boyutunun zayıf kaldığı görülmektedir. Ayrıca metinlerde birlikte yaşama konusunda, dört söylem üretilerek birlikte yaşama kültürü söylemler üzerinden tesis edilmeye çalışılmaktadır. Bu konuda ilk söylem, metinlerde "Çanakkale Ruhu" olarak adlandırılan bir bilinci toplumda oluşturmayı kapsar. Birlikte yaşama kültürünü, birlikte var olmaya endeksleyen ve tüm farklılıklara rağmen birlikte mücadele edilerek düşmana karşı zafer elde eden tarihsel bir gerçekliğe dayanmaktadır. Kaldı ki bu söylemle, "bu vatanı farklılıklarımızla birlikte biz kurduk, biz yaşatacağız" mesajı verilmektedir. İkinci söylem, metinlerde en çok geçen, bir tipoloji olarak ensar-muhacir yardımlaşması üzerinden üretilen, "ensar-muhacir kardeşliğiı"dir. Suriyeli sığınmacıları muhacir, Türkiye toplumunu ensar olarak kodlayan bu söylemin, toplumda önemli bir karşılık bulduğu düşünülmektedir. Üçüncü söylem; fitne, fesat ve kaos uyarıları ve ihtimalleri hatırlatılarak, toplumun "birlikte ve kardeşçe yaşamasının, dış güçler ya da terör örgütleri tarafından hedef alındığı" mesajı üzerine kurulmuştur. Zira bu hutbelerle toplumda dayanışma ve yardımlaşma bilincinin oluşturularak bir kimlik ve aidiyet üretiminin hedeflendiği düşünülmektedir. Toplumda kaos veya infial oluşturma potansiyeline sahip olayların hemen sonrasında genellikle bu tür hutbelerin okutulması, insanların tahrike kapılmaması, öteki olarak ifade edilen kişilere zarar vermemesi kısacası "oyuna gelmemesi" içindir. Dördüncü ve son söylem ise, metinlerde "birlikte yaşama stratejisinin umudu" olarak Türkiye"nin gösterilmesidir. Savaşlardan ve zulümden kaçan insanların sığınağı ve "kurtarıcısı" olarak Türkiye gösterilmekte, toplumumuzun sığınmacılarla tarihten gelen bağlarının olduğuna, ayrıca Türkiye'nin dünyadaki "mazlumların sesi" olduğuna da dikkat çekilmektedir. Dolayısıyla geçmişte (Osmanlı dönemi kastedilerek) olduğu gibi bugün de birlikte yaşayabilmenin umudu olarak bu toprakların varlığı hatırlatılmaktadır. Sonuç olarak hutbelerde geçen söylemler değerlendirildiğinde, bu metinlerin birlikte yaşama konusunda toplumu bilinçlendiren ve telkin eden yönlerinin olduğu ve bu anlamda birlikte yaşama tecrübesine önemli kazanımlar sağladığı görülmektedir. 


\section{SUMMARY}

Plurality in today's world has been forming the new ontological construct of the societies. In the history of humanity, for the first time, today's societies have been living so close to each other. This situation has caused the increasing level of the awareness regarding identities and cultures. Yet the important proportion of world population has been maintaining their lives in new settlements by leaving their provinces of birth due to some reasons such as wars, economic reasons, educational purposes, natural disasters, and any other reasons. On the other hand, another important part of world's population has been searching for a new homeland by not staying permanently on the places they previously migrated to. This new situation of the world necessitates more than one cultural element to live on the same place or territory. Thus, the problem of co-existence of different social elements has started to be discussed through some conceptualizations such as "multiculturalism", "social or cultural reconciliation", "cultures to understand each other", "inter-cultural communication", and "co-existence".

As in most of the countries in the World, many problems in terms of the issue of living together have been encountered in Turkey, as well. In today's Turkey, the issue of living together, which is experienced in ethnical basis and expressed as "Kurdish Issue", has started to include a new issue, so-called "Syrians Issue", in the recent years due to the migration of Syrian asylum-seekers to Turkey because of the Syrian War. The issue of Syria and the fact that almost 3 million Syrian asylum seekers have been attracting attention in the everyday life of the society makes the issue of co-existence more visible. Presidency of Religious Affairs (PRA), which represents the institution of religion, has not been unconcerned with this problem. Presidency of Religious Affairs has dealt with this issue during the Jumuah (Friday) and Eid prayers and attempted to develop a tone (language) appropriate to Islamic tenets.

The Presidency of Religious Affairs has established a strategy for the political and social events that develop at the global and/or national basis, which constitute the agenda of the society and discourses appropriate to this strategy have usually been submitted to the attention of the society through khutbahs. In these khutbahs, there are some issues, which occupy the world's agenda by ethnical and religious discriminations such as DAESH, Islamophobia, problems in Muslim World, war in Syria, Arab Spring, Al-Aksa Mosque, and Palestine issue. In addition, issues that are of particular concern to Turkey such as violence against women, Syrian asylum-seekers, natural disasters and mine disasters, chaos and social disturbance have been included in these khutbahs. Through these khutbahs, the Presidency of Religious Affairs has attempted to develop discourses such as the ability to set-up co-existence and cultural diversity, respect for differences and the right to life, helping asylum-seekers, and social prosperity for the brotherhood. Among these themes, the discourse of living together is an issue that is mostly expressed and reminded in khutbahs. In addition, it is known that PRA focuses on a specific theme each year for Holy Birth Week (of Prophet Mohammad) and during the year, this theme always constitutes the main agenda of the activities. PRA has laid emphasis on the theme of "living together" for two years within the last ten years. For example, the theme of Holy Birth Week for 2008 was "The Experience of Living Together in Islamic Civilization" (PRA, 2009) and theme determined for 2015 was "His Holiness (Hz.) Prophet and Moral of Living Together".

Mosques are important places on the daily lives of Muslims. In mosques, khutbahs, which are prepared by Presidency of Religious Affairs or Provincial Offices of Mufti, are 
given during the Jumuah and Eid prayers. Khutbahs aim at indoctrinating Muslims about political, social and the other issues that constitute the Muslims' agenda besides subjects like worship and morality. These agendas consist of some problems such as epidemic, war, discrimination, genocide, migration, urbanization, crime, hunger and drought, which have been experienced in today's societies and which cause social and political transformations. These events are important in terms of both influencing the majority of world's population and generally occurring in the areas where Muslims have been intensively living. Moreover, issues like living together, respect for diversity, etc. have been moved to the agenda of the social sciences. In this study, re-production of the co-existence culture of Islam through the khutbahs will be analysed and discourse analyses of khutbahs will sociologically be evaluated. Within this context, sociological analysis of the "co-existence" discourse given in khutbahs during Jumuah and Eid prayers will be made. In addition, discourse analyses of the khutbahs themed "living together", "respect for diversity" will be discussed in the exemplification of some social and political events. For that purpose, 87 khutbahs given in Jumuah and Eid prayers between the years of 2013 and 2015 will be examined. In line with the basis of issues such as the Syrian issue, Syrian asylum-seekers, terror and ethnic conflicts which these khutbahs deal with, the discourses that construct the culture of living together in the khutbahs will be questioned.

Discourse analyses of the khutbahs will be handled under the titles of "religious references of living together", "historical code of co-existence and the spirit of Çanakkale", "to be able to construct co-existence by the discourse of ansar-muhajir", "fitna and chaos: the decapitators of living together", "the hope for living together: Turkey". Besides, it will be evaluated at which level the Presidency of Religious Affairs deals with co-existence culture and morality, cultural and historical dimensions of the morality of co-existence, application proposals in daily life practices, and what the discourses and references of coexistence are.

SEFAD, 2017 (38): 507-532 


\section{KAYNAKÇA}

Adana Müftülüğü İrşad Kurulu (2015). "Suriyeli Kardeşlerimize Yardım Kampanyası". Cuma Hutbesi. 09.01.2015

AKTAY, Yasin (1998). "Kültürel Sahihlik Söylemleri ve Modernlik". Tezkire (14-15): 13-42.

AKTAY, Yasin (2003). "Küreselleşme ve Çokkültürlülük". Tezkire (35): 54-82.

ARICI, Mehmet (2014). “Nefis Muhasebesi”. Cuma Hutbesi. 03.01.2014.

AYDIN, Mustafa (2003). "Birlikte Yaşama' Bağlamında Çokkültürlülük Sorunu”. Tezkire (35): 39-53.

AYDOĞAN, Mevlüt (2013). "Fitne ve Zararlar1". Cuma Hutbesi. Adana İl Müftülüğü. 29.11.2013.

BEŞİRLİ, Hayati (2006). “Diyanet İşleri Başkanlığı'nın Camilerde Okuttuğu Hutbelerin Sosyolojik Analizi". Sakarya Üniversitesi Fen-Edebiyat Fakültesi Dergisi 8 (2): 143-171.

CAN, İslam (2013). "Çokkültürlülük Tartışmaları Işığında Adalet ve Kalkınma Partisi (AKP)'nin Çokkültürlü Politikalarını Anlamaya Giriş". II. TLÇK Bildiriler Kitabı I. Bursa: Bursa Büyükşehir Belediyesi Kitaplığı. 115-132.

CAN, İslam (2015). Türkiye'de Siyasal Güven (Liderler Kurumlar Süreçler). İstanbul: Açılım Yay. CEVIZZVI, Ahmet (2002). “Söylem”. Paradigma Felsefe Sözlüğ̈̈. İstanbul: Paradigma Yay. 5. bs. ÇELIK, Ali Hayri (2014). “Hiç Kimse Kimsesiz Kalmasın”. Cuma Hutbesi. 11.07.2014

DEMIR, Metin (2012). "Çevreye Minberden Bakmak: Cuma Hutbelerinde Çevre Sorununun Sunumu". Insan ve Toplum 2 (3): 5-32.

DEMIR, Zekiye (2013). “Diyanet Hutbelerinde Kadın Söylemi (2001-2011)”. Toplum Bilimleri 7 (14): 95-118.

DHGM (2013a). "Muharrem Ayı ve Kerbela". Cuma Hutbesi. 08.11.2013

DHGM (2013b). "Kurbanlarımızla Pekişsin Kardeşliğimiz". Cuma Hutbesi. 04.10.2013

DHGM (2014a). “Nasıl Bir Kardeşlik”. Cuma Hutbesi. 31.01.2014

DHGM (2014b). "Kimsesizlerin Kimsesi Olabilmek". Cuma Hutbesi. 11.07.2014

DHGM (2014c). “Hicret: Fitrata Yapılan Yolculuk”. Cuma Hutbesi. 24.10.2014

DHGM (2014d). “Ortak Hüzün ve İbret Ayı: Muharrem”. Cuma Hutbesi. 31.10.2014

DHGM (2014e). “Dilin Esiri Olmayalım!”. Cuma Hutbesi. 28.11.2014

DHGM (2015a). “Mevlid: Rahmet Elçisinin Dünyayı Teşrifi”. Cuma Hutbesi. 02.01.2015

DHGM (2015b). "Allah'in Son Dini İslam". Cuma Hutbesi. 30.01.2015

DHGM (2015c). "Çanakkale Şehitlerine...". Cuma Hutbesi. 13.03.2015

DHGM (2015d). “İnsanı İyilik Yaşatır”. Cuma Hutbesi. 20.03.2015

DHGM (2015e). “Hz. Peygamber ve Birlikte Yaşama Ahlakı". Cuma Hutbesi. 10.04.2015

DHGM (2015f). “Dünya Bize, Biz Birbirimize Emanetiz!”. Cuma Hutbesi. 17.04.2015

DHGM (2015g). “Manevi Coşkunun Zirvesi: Üç Aylar”. Cuma Hutbesi. 24.04.2015

DHGM (2015h). "İslam, Irkçıllğın Her Türlüsünü Reddeder”. Cuma Hutbesi. 05.06.2015

DHGM (2015i). "Vakit İyilik Vakti: Bu Ramazan ve Her Ramazan”. Cuma Hutbesi. 19.06.2015

DHGM (2015k). "Tevhid İle Gelen Vahdet". Cuma Hutbesi. 26.06.2015

DHGM (2015m). “Cennet Kapılarının Anahtarı: Yetimler”. Cuma Hutbesi. 03.07.2015

DHGM (2015n). "Ramazan Bayramı". Ramazan Bayramı Hutbesi. 17.07.2015

DHGM (2015p). “Gün Birlik ve Dirlik Günüdür!”. Cuma Hutbesi. 24.07.2015

DHGM (2015r). "Birlik ve Beraberliğimizin Harcı: Kardeşliğimiz". Cuma Hutbesi. 21.08.2015.

DİB (2007). Diş

Genelge. http://www2.diyanet.gov.tr/HukukMusavirligi/Mevzuat/Foyvolant Dis Gene lge 2007.pdf [04.07.2017]. 
DİB (2009). İslam Medeniyetinde Bir Arada Yaşama Tecrübesi. Ankara: Türkiye Diyanet Vakfı Yay.

DİB (2013). “Ömür Sermayesi Tükenirken...”. Cuma Hutbesi. 27.12.2013.

DİB (2014a). "Müminler Tek Vücut Gibidir". Cuma Hutbesi. 16.05.2014.

DİB (2014b). "Mazlumların Ümidi Olabilmek". Cuma Hutbesi, 18.07.2014.

DİB (2014c). “Ramazan Bayramı”. Bayram Hutbesi, 28.07.2014.

DİB (2015a). "Her Can Kutsal ve Dokunulmazdır!”. Cuma Hutbesi. 20.02.2015.

DİB (2015b). “Kadına El Kalkmaz!”. Cuma Hutbesi. 20.02.2015.

DİB (2016a). 15 Temmuz 2016

Genelgesi. http://www2.diyanet.gov.tr/HukukMusavirligi/SiteAssets/Sayfalar/genelgele r/15\%20Temmuz\%202016\%20Genelgesi.pdf [04.07.2017].

DİB (2016b). “Din Şurası Sonuç Bildirgesi Açıklandı”.

Yenişafak. http://www.yenisafak.com/hayat/din-surasi-sonuc-bildirgesi-aciklandi2505531 [04.07.2017].

DİB (2017). Kendi Dilinden FETÖ: Örgütlü Bir Din İstismarı. Ankara: Diyanet İşleri Başkanlığ1 Yay.

DOĞAN, Recai (1998). "Cumhuriyet Öncesi Dönemde Yaygın Din Eğitimi Açısından Hutbeler". Dini Araştırmalar 1 (2): 5-51.

FORSTER, Nick (1994). "The analysis of company documentation". Qualitative methods in organizational research: A pratical quide. ed. C.Cassell \& G. Symon. London: Sage.

FUKUYAMA, Francis (2009). Büyük Çözülme: İnsan Doğası ve Toplumsal Düzenin Yeniden Oluşturulması. çev. Hasan Kaya. İstanbul: Profil Yayıncılık. 5. Bs.

GÖRMEZ, Mehmet (2017). “Sunuş". Kendi Dilinden FETÖ: Örgütlü Bir Din İstismarı. Ankara: Diyanet İşleri Başkanlığı Yay. 7-8.

HABERMAS, Jürgen (2010). "Demokratik Anayasal Devlette Tanınma Savaşımı", Çokkültürcülük Tanınma Politikası, ed. A. Gutmann. çev. M. H. Doğan. İstanbul: Yapı Kredi Yay.

KOÇYİĞİT, Tahsin (2013). "Vaazlarda Hz. Peygamberi Anlatma Yöntemine İlişkin Değerlendirmeler". Vaaz ve Vaizlik Sempozyumu Bildiri Kitabı I. Ankara: Diyanet İşleri Başkanlığı Yay. 418-436.

KÜLEKÇİ, Cahit (2013). “Illk Dönem İslam Siyasi Tarihinde Hutbe Uygulaması”. Turkish Studies 8 (7): 307-321.

KYMLICKA, Will (1998). Çokkültürlü Yurttaşlık/Azınlık Haklarının Liberal Teorisi. çev. A. Yılmaz. İstanbul: Ayrıntı Yay.

KYMLICKA, Will (2001). Politics in the Vernacular: Nationalism, Multiculturalism And Citizenship. New York: Oxford Universty Press.

METiN, Lokman (2014). “Çanakkale ve Milli Şuur". Cuma Hutbesi. 14.03.2014

ÖZBOLAT, Abdullah (2013). "Hutbelerde Söylem Değișimi-Diyanet Hutbeleri Örneği". Uluslararası Sosyal Araştırmalar Dergisi 7 (29): 662-679.

ÖZENSEL, Ertan (2012). "Çokkültürlülük Uygulaması Olarak Kanada Çokkültürlülüğü". Akademik Incelemeler Dergisi 7 (1): 55-69.

ÖZENSEL, Ertan (2013). “Doğu Toplumlarında ve Türkiye'de Birlikte Yaşama Arayış1: Çokkültürlülük mü? Yoksa Yeni Bir Model mi?”. Akademik Incelemeler Dergisi 8 (3): 1-17.

PAREKH, Bhikhu (2002), Çokkültürlülü̈̆̈̈̈ Yeniden Düşünmek. çev. B. Tanrıseven. Ankara: Phoenix Yay.

POLAT, İdris (2014). “Kültür Erozyonu”. Cuma Hutbesi. 14.11.2014. 
PUTNAM, Robert D., (1993), Making Democracy Work: Civic Traditions in Modern Italy, New Jersey: Princeton University Press.

SEZER, M. Ali (2014). “Selam ve Önemi”. Cuma Hutbesi. 17.01.2014.

ŞAN, M. Kemal (2005). “Farklılık ve Çokkültürlülük Siyasetleri Üstüne Bir Deneme”. Milel ve Nihal 3 (1-2): 69-117.

TAYLOR, Charles (2010). “Tanınma Politikası”, Çokkültürcülük/Tanınma Politikası. ed. A. Gutmann. çev. Y. Salman. İstanbul: Yapı Kredi Yay.

VATANDAŞ, Celalettin (2002). Küreselleşme Sürecinde Toplumsal Kimlikler ve Çokkültürlülük. İstanbul: Değişim Yay.

Veda Hutbesi http://www.vedahutbesi.gen.tr/, [25.07.2017].

WOLF, Susan (2010). "Yorum". Çokkültürcülük/Tanınma Politikası. ed. A. Gutmann. çev. R. Urgan. İstanbul: Yapı Kredi Yay.

YALÇIN, Metin (2014). “Mevlid Kandili”. Cuma Hutbesi. 10.01.2014

YAŞAROĞLU, M. Kamil (2016). “Diyanet İşleri Başkanlığı'nın Hutbe Hizmetlerine Genel Bir Bakış". Yakın Doğu Üniversitesi İlahiyat Fakültesi Dergisi 2 (1): 93-107.

YILDIRIM, Ali- ŞIMŞSK, Hasan (2013). Sosyal Bilimlerde Nitel Araştırma Yöntemleri. Ankara: Seçkin Yay. 9. bs.

YILMAZ, H. Kamil (2013). “Kurban Bayramı”. Kurban Bayramı Hutbesi. 15.10.2013.

ZENGİN, H. Kader (2013). “Son Dönem Cumhuriyet Hutbelerinin İçerik Analizi (2003-2011 Yılları Arası)". Yaygın Din Eğitimi Sempozyumu II. Ankara: Diyanet işleri Başkanlığı Yay. 121-147.

ZENGIN, Z. Salih (2008). “Osmanlılar Döneminde Yaygın Din Eğitimi Faaliyeti Olarak Hutbeler". Ç.Ü. Sosyal Bilimler Enstitüsü Dergisi 17 (1): 379-398. 